\title{
Interaction with the host: the role of fibronectin and extracellular matrix proteins in the adhesion of Gram-negative bacteria
}

\author{
Diana J. Vaca ${ }^{1} \cdot$ Arno Thibau $^{1} \cdot$ Monika Schütz $^{2} \cdot$ Peter Kraiczy $^{1} \cdot$ Lotta Happonen $^{3} \cdot$ Johan Malmström $^{3}$. \\ Volkhard A. J. Kempf ${ }^{1}$ (D)
}

Received: 24 July 2019 / Accepted: 14 November 2019 / Published online: 29 November 2019

(C) The Author(s) 2019

\begin{abstract}
The capacity of pathogenic microorganisms to adhere to host cells and avoid clearance by the host immune system is the initial and most decisive step leading to infections. Bacteria have developed different strategies to attach to diverse host surface structures. One important strategy is the adhesion to extracellular matrix (ECM) proteins (e.g., collagen, fibronectin, laminin) that are highly abundant in connective tissue and basement membranes. Gram-negative bacteria express variable outer membrane proteins (adhesins) to attach to the host and to initiate the process of infection. Understanding the underlying molecular mechanisms of bacterial adhesion is a prerequisite for targeting this interaction by "anti-ligands" to prevent colonization or infection of the host. Future development of such "anti-ligands" (specifically interfering with bacteria-host matrix interactions) might result in the development of a new class of anti-infective drugs for the therapy of infections caused by multidrug-resistant Gram-negative bacteria. This review summarizes our current knowledge about the manifold interactions of adhesins expressed by Gram-negative bacteria with ECM proteins and the use of this information for the generation of novel therapeutic antivirulence strategies.
\end{abstract}

Keywords Gram-negative bacteria $\cdot$ Adhesins $\cdot$ Extracellular matrix proteins $\cdot$ Fibronectin $\cdot$ Collagen $\cdot$ Laminin

\section{Introduction}

The capacity to adhere to host cells and thereby avoid clearance by the host defense systems (e.g., via peristalsis, fluid flow or innate immunity) is an important determinant for a successful colonization by bacterial pathogens. Adhesion to the host cells can facilitate translocation of pathogenic

Edited by Dirk Linke.

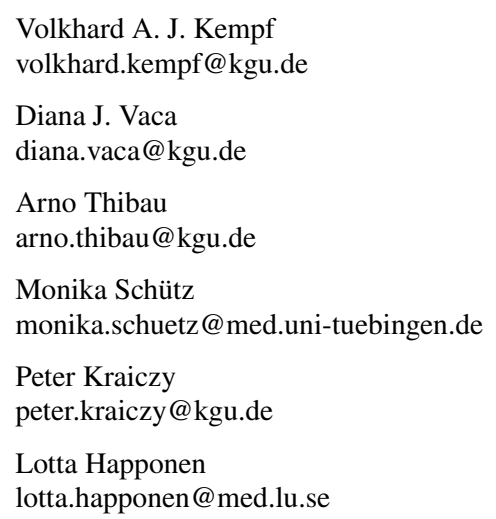

bacteria across the cellular and tissue barriers by generating a stable starting point on which the microorganism can persist, replicate, and internalize into host cellular compartments. Once a stable adhesion to host cells is established, pathogens are able to spread within the host and express and/or release further virulence factors enabling subsequent steps of infections. Such virulence factors include, e.g., bacterial toxins (modulating host cell functions), cell surface carbohydrates or proteins (protecting the bacterium from

Johan Malmström

johan.malmstrom@med.lu.se

1 Institute for Medical Microbiology and Infection Control, University Hospital, Goethe University Frankfurt am Main, Paul-Ehrlich-Str. 40, 60596 Frankfurt, Germany

2 Institute for Medical Microbiology and Infection Control, University Hospital, Eberhard Karls-University, Tübingen, Germany

3 Division of Infection Medicine, Department of Clinical Sciences, Faculty of Medicine, Lund University, Lund, Sweden 
host defense), and exoenzymes (contributing to bacterial dissemination).

A group of proteins exposed on the pathogen's surface called "adhesins" has been identified as the molecular basis for bacterial adherence to certain host molecules. The way that different bacterial populations take advantage of their adhesins and how they bind to their specific receptors within the host is decisive for the particular type of disease caused by a particular organism. Adhesins are involved in biofilm formation and have proven to undermine host strategies for pathogen clearance [1, 2]. Furthermore, bacterial adhesion to host cell surfaces activates both bacterial and host signaling, subsequently enabling bacterial spread and the evasion of innate and cellular immune responses [3]. On the host side, the extracellular matrix (ECM) is one of the most important proteinaceous tissue components, due to the wide distribution of ECM in the connective tissue and basement membranes [4]. Targeting of ECM proteins for adherence is, therefore, one of the major strategies for pathogen colonization and host invasion [4].

Bacterial binding capacity to ECM proteins was first described over 40 years ago, with the report of Staphylococcus aureus binding to fibronectin [5]. Since then, our knowledge about the mechanisms underlying host-pathogen interactions has increased significantly. This resulted in promising ideas for inhibiting such interactions for the future development of anti-bacterial therapeutics. In this review, we summarize the principal ECM proteins involved in the adhesion processes of Gram-negative bacteria, the impact on virulence and pathogenesis, and how to use this knowledge in terms of generating novel antivirulence-therapeutic strategies.

\section{Extracellular matrix proteins involved in the adhesion of Gram-negative bacteria}

The ECM is a highly dynamic structure having various functions. It consists of numerous macromolecules in charge of, e.g., the structural support and scaffolding of cellular barriers, cellular signaling, and the regulation of physiological processes. The ECM is composed of proteoglycans and glycoproteins secreted locally and brought together into an organized network. The main fibrous proteins forming parts of the ECM are collagen, elastin, fibronectin, laminin, and vitronectin [6], making these molecules a preferred target for bacterial adhesion.

\section{Collagen}

Collagen is the major glycoprotein representing 30\% of the total protein content in the human body. Its presence is crucial for maintaining tissue structure, cell adhesion, embryonic development, and many other functions. Apart from mammals and some other vertebrates, collagen has been identified in many invertebrate organisms, evidencing the conservation and importance of the molecule throughout evolution [7, 8]. The latest report described a total of 28 collagen types encoded by more than 45 genes distributed in body tissue and organs $[9,10]$. Initially, it was thought that all types of collagen were secreted by fibroblasts which are present in the connective tissue [11] but the production of certain types of collagen by epithelial cells indicates the broad distribution of the molecule in the human body [10]. Under normal conditions, collagen is degraded extracellularly by tissue collagenases, belonging to the class of matrix metalloproteinases [9].

Collagen consists of $\alpha$-chains and the variability in the number of $\alpha$-chains present in the molecule defines the different collagen types distributed in the human body. Despite the presence of multiple isoforms and tissue expression levels, all the different types of collagen share common structures [10]. The most significant structure is the presence of Gly-X-Y repeats located in the central part of the $\alpha$-chain, known as the "collagenous domain". A triple helix structure is formed by regular hydrogen bonding between proline and glycine residues [12]. In addition to the collagenous domain, there are regions lacking the Gly-X-Y repeats named "noncollagenous domains". The presence of these long noncollagenous domains along the molecule creates breaks in the triple helix conformation, while the non-collagenous domains in the $\mathrm{N}$-terminal and $\mathrm{C}$-terminal ends are removed by procollagen $\mathrm{N}$ - and $\mathrm{C}$-proteinases to allow the assembly into fibrils [13]. The supramolecular association occurs after extracellular release and further assembly into networks or fibrils including other ECM proteins.

The collagen protein family is widely present in skin (collagen type I in association with collagen types III, V, VII, XII, XIII and XIV), in bones (collagen type I in association with collagen types XXIV), in cartilage (collagen type II in association with IX, X, XI and XIII), and in basement membranes (collagen type IV in association with collagen type XVIII) $[9,10]$. The presence of collagen-binding proteins (collagen-BPs) in pathogenic bacteria is, therefore, not incidental but has evolved because of the broad distribution of this ECM protein in organs and tissue. The majority of adhesin-host protein interactions observed in Gram-negative bacteria have been associated with collagen type I, IV, and $\mathrm{V}$ [4].

\section{Fibronectin}

Fibronectin (Fn) is a multidomain glycoprotein present in body fluids and on cell surfaces with the principal function of connecting the cell to the exterior ECM. Two major forms of Fn are present in the body: a soluble (plasma) and 
an insoluble (cellular) form. Plasmatic Fn is produced by hepatocytes and is, therefore, present in blood, saliva, and other fluids, playing important roles in blood clotting [14]. Cellular Fn is secreted by fibroblasts and endothelial cells and is incorporated on the cell surface into a fibrillar-type matrix $[15,16]$. Turnover of ECM proteins is an important mechanism to remove biologically active proteins from the extracellular environment. Fn degradation occurs intracellularly after endocytosis of non-polymerized Fn molecules [17].

The Fn molecule is a heterodimer composed of two splice variants of about 230 and $270 \mathrm{kDa}$ connected by a C-terminal disulfide bond (see Fig. 1). In general, the Fn structure is organized into 12 type I repeats (FnI), two type II repeats (FnII), and a variable number (between 15 and 18) of type III repeats (FnIII). Differences between the splice variants modify the number of modules in FnIII [15, 16, 18]. Additionally, cellular Fn can include EIIIA and EIIIB domains, which notably are not present in the soluble molecule [19, 20].

Fn mediates important human protein-protein and protein-oligosaccharide interactions during the formation of the ECM [21]. The FnI - FnI $_{5}$ components are the most conserved Fn region across vertebrates [21]. This domain is required for the proper assembly of the ECM and binds to heparin (lower affinity) and fibrin (stronger affinity). Moreover, this domain is also the major fibrin-binding site in the Fn molecule. The interaction between Fn and fibrin is important for cell adhesion, cell migration into fibrin clots, and for macrophage removal from circulation after a trauma or in the case of inflammation. Another region consisting of $\mathrm{FnI}_{6}, \mathrm{FnII}_{1-2}$, and $\mathrm{FnI}_{7-9}$, promotes collagen binding. This interaction has been suggested to occur either to mediate cell adhesion or to favor clearance of denatured collagenous material from blood and tissue. The FnIII domain mediates cell attachment via integrins (cell-surface heterodimeric receptors) in the RGD loop located at the $\mathrm{FnIII}_{8-10}$ area. The interaction via integrins allows the linkage of ECM with the intracellular cytoskeleton. The FnIII ${ }_{12-14}$ modules contain the strongest interaction site necessary for heparin-binding. It has been proposed that this region facilitates the formation of protein interactions for insoluble fibril assembly, whereas in some cell types the heparin-binding domain promotes cell adhesion. A second fibrin-binding site is located at the C-terminal FnI $\mathrm{I}_{10-12}$ modules [18, 21-23].

The presence of bacterial Fn-binding proteins (FnBPs) was demonstrated by the inactivation of the respective FnBP genes and the observation of diminished or abolished bacterial adhesive characteristics in mutants lacking the expression of the protein. The observation of a Fn-binding repeat sequence within the adhesins $(\mathrm{GGXXXXV}(\mathrm{E} / \mathrm{D})(\mathrm{F} / \mathrm{I})$ $\mathrm{XX}(\mathrm{D} / \mathrm{E}) \mathrm{T}(\mathrm{Xx} 15) \mathrm{EDT})$ has been described for certain bacterial proteins [24]. On the other hand, a canonical binding site in the Fn molecule located in the $\mathrm{FnI}_{2}-\mathrm{FnI}_{5}$ region has been identified due to the interaction of many FnBPs in this area $[22,25]$. Notwithstanding, other non-canonical bacterial binding sites associated with positions $\mathrm{FnI}_{6}, \mathrm{FnII}_{1-2}$, $\mathrm{FnI}_{7-9}, \mathrm{FnIII}_{9-10}$, and $\mathrm{FnIII}_{12}$ have also been identified in the Fn molecule (see Fig. 1).

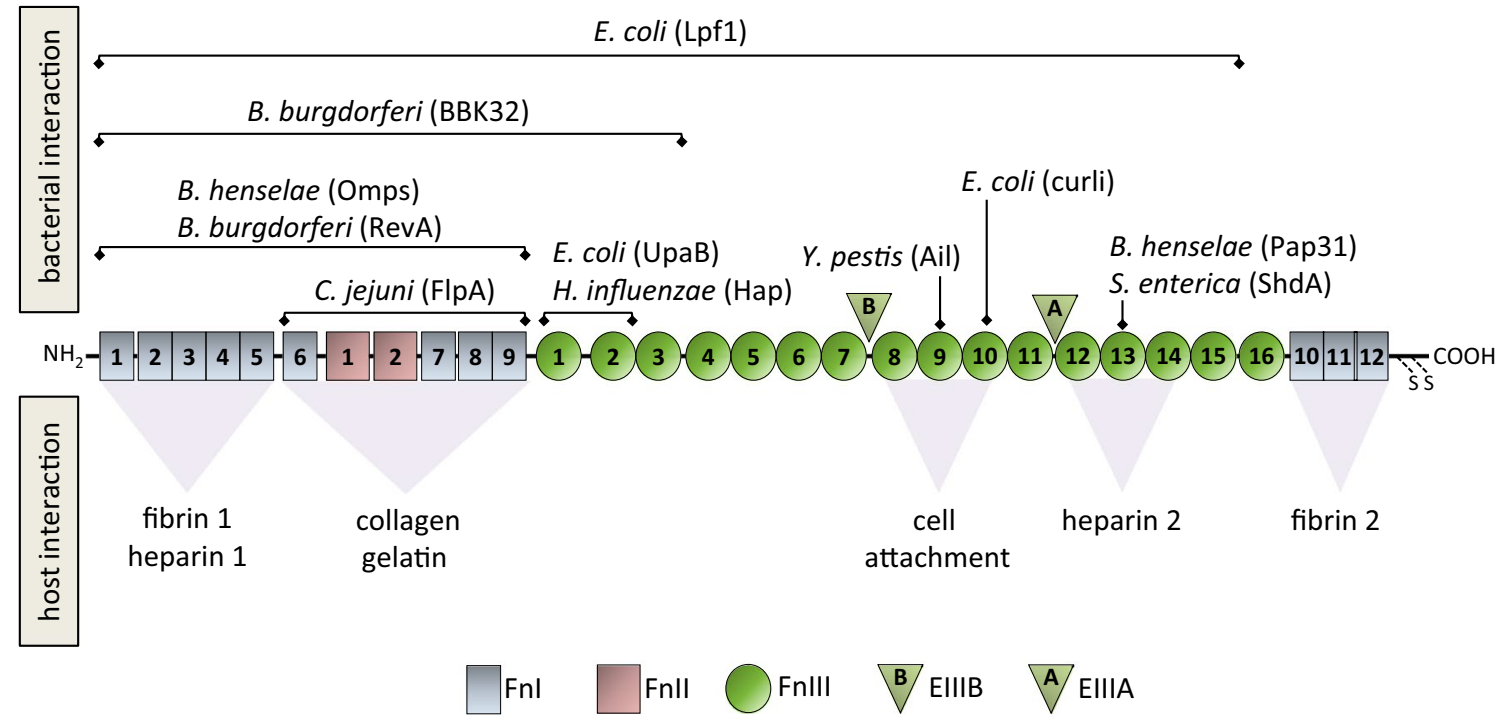

Fig. 1 Schematic drawing of the fibronectin molecule (monomer) with selected bacterial protein-binding sites and selected host protein-protein interaction sites. Fibronectin (Fn) is a heterodimer composed of two splice variants connected by a C-terminal disulfide bond. The molecule contains nine Fn type I repeats, two Fn type II repeats, and between 15 and 18 Fn type III repeats. In cellular Fn, EIIIA (A) and EIIIB (B) domains are present as a result of alternative splicing Adapted from [202] 


\section{Laminin}

Laminin ( $\mathrm{Ln})$ is a multifunctional molecule with a total of 15 heterotrimeric isoforms differentially distributed in basement membranes, connective tissue, cell surface, skin, and blood vessels. This ECM protein is in charge of maintaining the structural scaffold, cell migration, and signaling [4]. Plasmin degrades Ln that is located in the basement membrane at the dermal-epidermal junction and in the hippocampus [26, 27].

Ln consists of $\alpha-(400 \mathrm{kDa}), \beta-(200 \mathrm{kDa})$, and $\gamma-(200 \mathrm{kDa})$ chains, independently expressed and interconnected via disulfide bonds at their C-terminal regions (see Fig. 2). Ln trimerizes prior to its extracellular secretion and then forms networks cooperating with other ECM proteins. The first $\mathrm{N}$-terminus (240-250 amino acid residues: LN domains) are well conserved among $\mathrm{Ln}$ isoforms and are involved in the polymerization of the molecule. The epidermal growth factor-like (LE) domains are associated with functions such

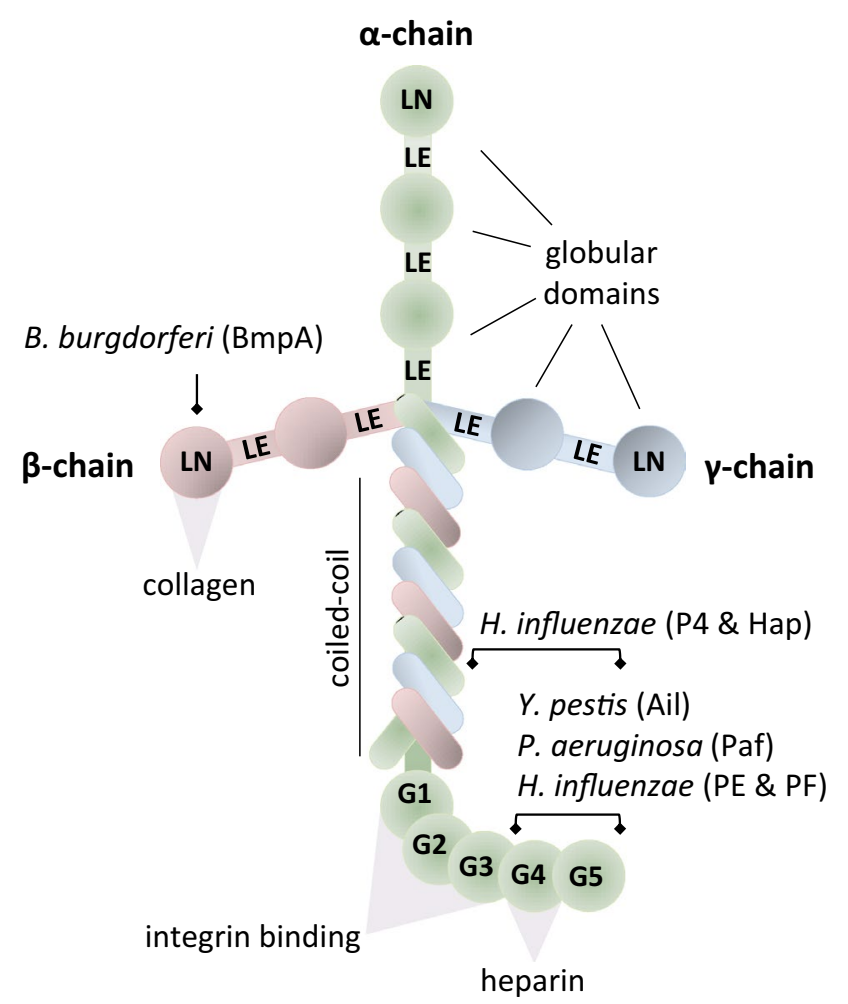

Fig. 2 Schematic drawing of the laminin molecule (heterotrimer) with selected bacterial protein-binding sites and selected host protein-protein interaction sites. Laminin ( $\mathrm{Ln})$ consists of $\alpha-(400 \mathrm{kDa})$, $\beta$ - $(200 \mathrm{kDa})$, and $\gamma-(200 \mathrm{kDa})$ chains interconnected with disulfide bonds. Ln domains (N-terminus) are involved in the polymerization of the molecule. The epidermal growth factor-like (LE) domains interconnect the globular domains. The coiled-coil region is present in all chains and their interactions maintain the structure. The C-terminus contains five globular domains (G1-G5) important for cellular scaffold functions as signaling, growth, and development and interconnect the globular domains of the Ln molecule. Finally, there is the coiled-coil region that consists of 600 amino acids and interacts with other proteins and receptors [4].

The Ln molecule has been found widely distributed in the renal parenchyma including glomeruli and tubules, and in gastric mucosa. The presence of Ln-Binding Proteins (LnBPs) has been demonstrated in Gram-negative pathogens such as Escherichia coli, Haemophilus influenzae, Neisseria meningitidis, Helicobacter pylori, Yersinia enterocolitica, and Borrelia burgdorferi [4] (see Fig. 2).

\section{Adhesins of Gram-negative bacteria and cellular matrix protein interactions}

Bacterial adherence to host tissues represents the first and decisive step in the infection process. Although bacterial attachment seems to be beneficial for microorganisms, it may become a double-edged sword if, after attachment, the host immune signaling is activated and impedes internalization and phagocytosis strategies. To overcome this problem, bacteria can express surface structures to protect themselves from immune recognition and might employ further traits, such as protein secretion systems to modulate and to evade the host's immune system. Actually, tight adhesion can be an essential prerequisite to engage these important facilitators of infection [28]. A group of proteins, called adhesins, are in charge of keeping the pathogen in close contact with the host.

Adhesins are a highly diverse group of proteins with heterologous architecture and domain composition [29]. The complexity of the bacterial tools used for cell adhesion ranges from single monomeric proteins to intricate multimeric macromolecules. Among this group, Trimeric Autotransporter Adhesins (TAAs) are a type of adhesins presented on the outer membrane of many human pathogenic Gram-negative bacteria. These obligate homotrimeric proteins are secreted via the type Vc pathway and led across the inner membrane Sec-dependently by an N-terminal signal peptide. The $\mathrm{C}$-terminal $\beta$-barrel domain interacts with the $\beta$-barrel assembly machinery (BAM) in order to be inserted into the outer membrane [30-32]. Most likely, concurrently with the $\beta$-barrel insertion facilitated by the BAM, the long passenger domain (N-terminal: head, neck and stalk domains) is translocated through the barrel in a hairpin-conformation and ends up exposed on the bacterial surface $[33,34]$. So far, all the described TAAs have been functionally associated with adhesion properties [30, 35].

With a similar secretion mechanism, the classical autotransporters ("monomeric autotransporter adhesins") are secreted via the type Va pathway. Briefly, the autotransporter crosses the inner membrane by the Sec machinery and, once 
the protein is in the periplasm, distinct chaperone proteins maintain the unfolded structure of the autotransporter [30]. BAM recognizes the $\mathrm{C}$-terminal membrane anchor; this step aids the insertion of the $\beta$-barrel membrane anchor into the outer membrane [34]. The linker region forms a hairpin inside the barrel while the passenger domain crosses the pore. For some autotransporters, the linker region will be cleaved releasing the passenger domain into the extracellular environment [30, 31]. Monomeric autotransporters [e.g., Haemophilus adhesion and penetration protein (Hap), MisL and ShdA of Salmonella enterica serotype Typhimurium and UpaB of uropathogenic E. coli; see Table 1] are the most ubiquitous class of secreted proteins in Gram-negative bacteria and accomplish varied functions including cell adhesion, biofilm formation, and resistance to host defenses [36].

Other types of adhesins described in Gram-negative bacteria are pili or fimbriae. These filamentous surface proteins comprise a scaffold-like domain anchored to the bacterial membrane with strong binding specificities. Interestingly, some pathogens (e.g., Bartonella bacilliformis) harbor both types of adhesins (TAA BrpA/BbadA [37] and flagellin [38]). This suggests that such adhesins might play important roles in different conditions or at distinct stages of the infection process. This diversity and variability of adhesins even between species from the same genus of bacteria make the task of deciphering the precise mode of bacteria-host interaction challenging [39]. In the following paragraphs, known ECM binding adhesins will be discussed in more detail in accordance with the Gram-negative pathogen they belong (see Table 1).

\section{Acinetobacter baumannii}

In intensive care units, Acinetobacter baumannii is a significant cause of nosocomial infections (e.g., pneumonia, bacteremia, wound infections) [94]. The appearance of multidrug-resistant strains has allocated this bacterium on top of the World Health Organization (WHO) list of pathogens for which new therapeutics are urgently needed [95].

Taking into account the use of ECM proteins as docking sites, it can be speculated that, in tissue damage circumstances, the exposure of ECM proteins might favor adherence and biofilm formation, complicating A. baumannii infection treatment [40]. A. baumannii has shown affinity to collagen and Fn [96], but only recently, the virulence factors and mechanism of the disease have been described in more detail [97].

Acinetobacter trimeric autotransporter (Ata) is a surface adhesin crucial for biofilm formation and binding to ECM components (collagen types I, III, IV, and V and Ln), but not to Fn and collagen type II [40]. Deletion of ata significantly diminished the binding of $A$. baumannii to endothelial cells in static and dynamic conditions, thereby highlighting the importance of this adhesin in the persistence of infection [98]. Additionally, Ata proved to be a potential vaccine candidate against $A$. baumannii as it was observed that the application of Ata-specific antisera attenuated the course of infection in mice [41]. It is worth mentioning that ata was present in $78 \%$ of the sequenced A. baumannii isolates but only in 3\% of the closely related but much less human pathogenic A. calcoaceticus/A. pittii clade [99].

The impact of outer membrane proteins (OMPs) in the adhesion to Fn has been widely described [42]. The interaction occurring between OMPs and Fn might represent a critical step for lung epithelial colonization in A. baumannii mediated infections [97]. OmpA (previously known as Omp38) is a highly conserved OMP in clinical isolates and is one of the best-characterized virulence factors of $\mathrm{A}$. baumannii [100-102]. Expression of ompA is associated with the cytotoxicity to eukaryotic cells and the adhesion to Fn $[42,103]$. The interference of OmpA function by the pretreatment of A. baumannii with a binding-inhibiting synthetic hexapeptide resulted in a reduced bacterial adherence to lung human cells and Fn [104]. Moreover, Omp33 (also known as Omp33-36) is also involved in adhesion via Fn binding and invasion of human lung epithelial cells [42, 43, 105]. Finally, the TonB-dependent copper receptor (TonB), which facilitates the active transport of substances to the outer membrane, has also been described as a FnBP [42, 106].

\section{Bartonella spp.}

The genus Bartonella compromises at least three species of major medical interest: $B$. henselae (cat-scratch disease), $B$. quintana (relapsing fever), and $B$. bacilliformis (Carrion's disease). The bacterial transmission to humans occurs after contact with infected animals or via blood-sucking arthropods (vectors) [107]. Bartonella species are facultative intracellular bacteria with the capacity to colonize a wide broad of host cells, among them erythrocytes [108, 109], endothelial cells [110-113], monocytes, macrophages, and dendritical cells [114-116]. B. quintana and B. henselae have been described as endocarditis-causing agents [117-119]. The mechanisms occurring in infective endocarditis point to multifactorial events of bacterial adherence in which the interaction between bacterial adhesins and ECM proteins might fulfill a critical role even under pulsating and high shear stress conditions [98, 120, 121].

Bartonella adhesin A ( $\mathrm{BadA})$ is the representative adhesin of the species and was first described as a "type IVlike pilus" expressed by $B$. henselae [111]. Later research described the OMP as a TAA mediating bacterial binding to ECM proteins [44]. It was demonstrated that the presence of BadA in low passage bacteria facilitates adhesion and invasion in human epithelial cells [111]. After the utilization 


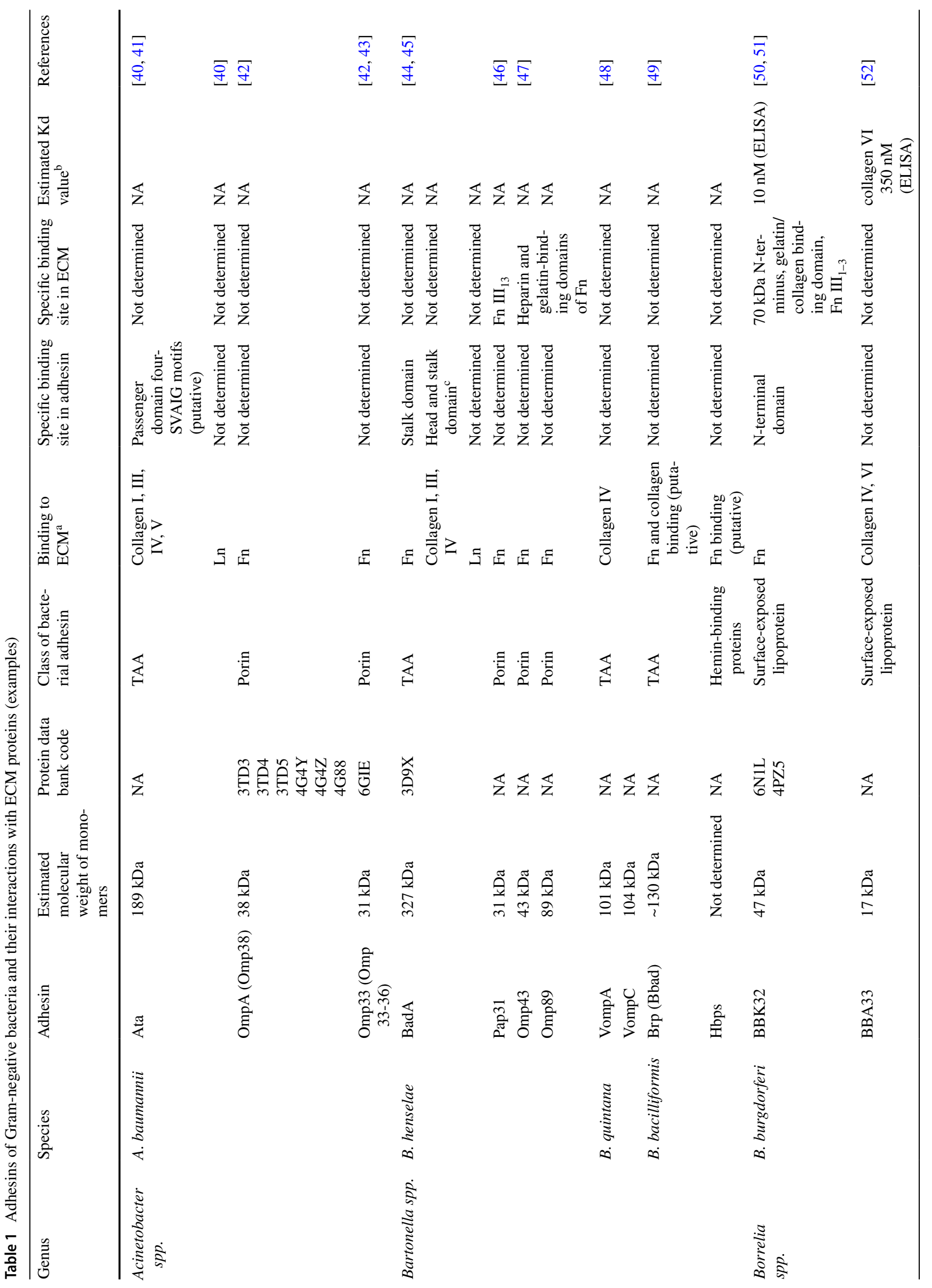




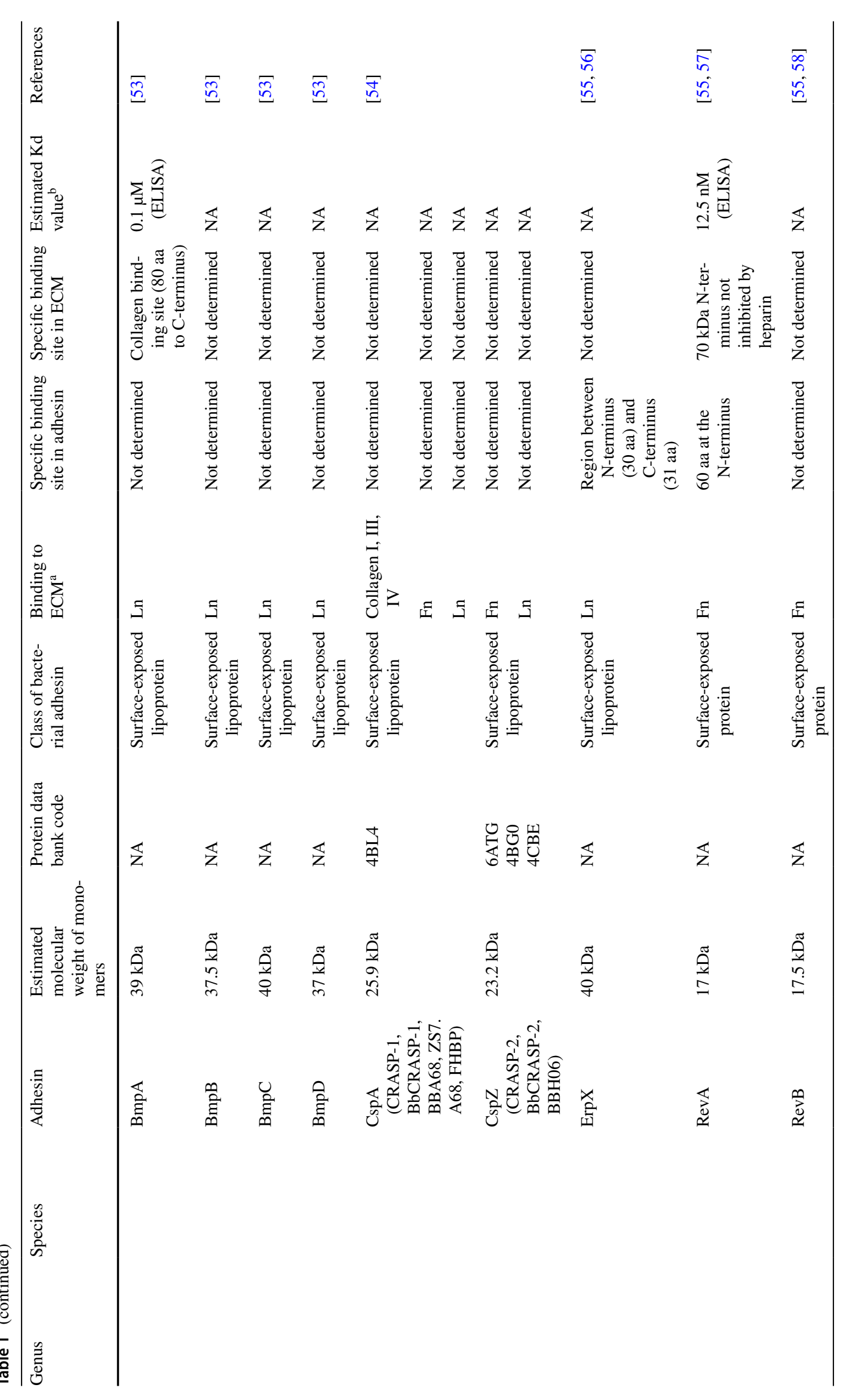




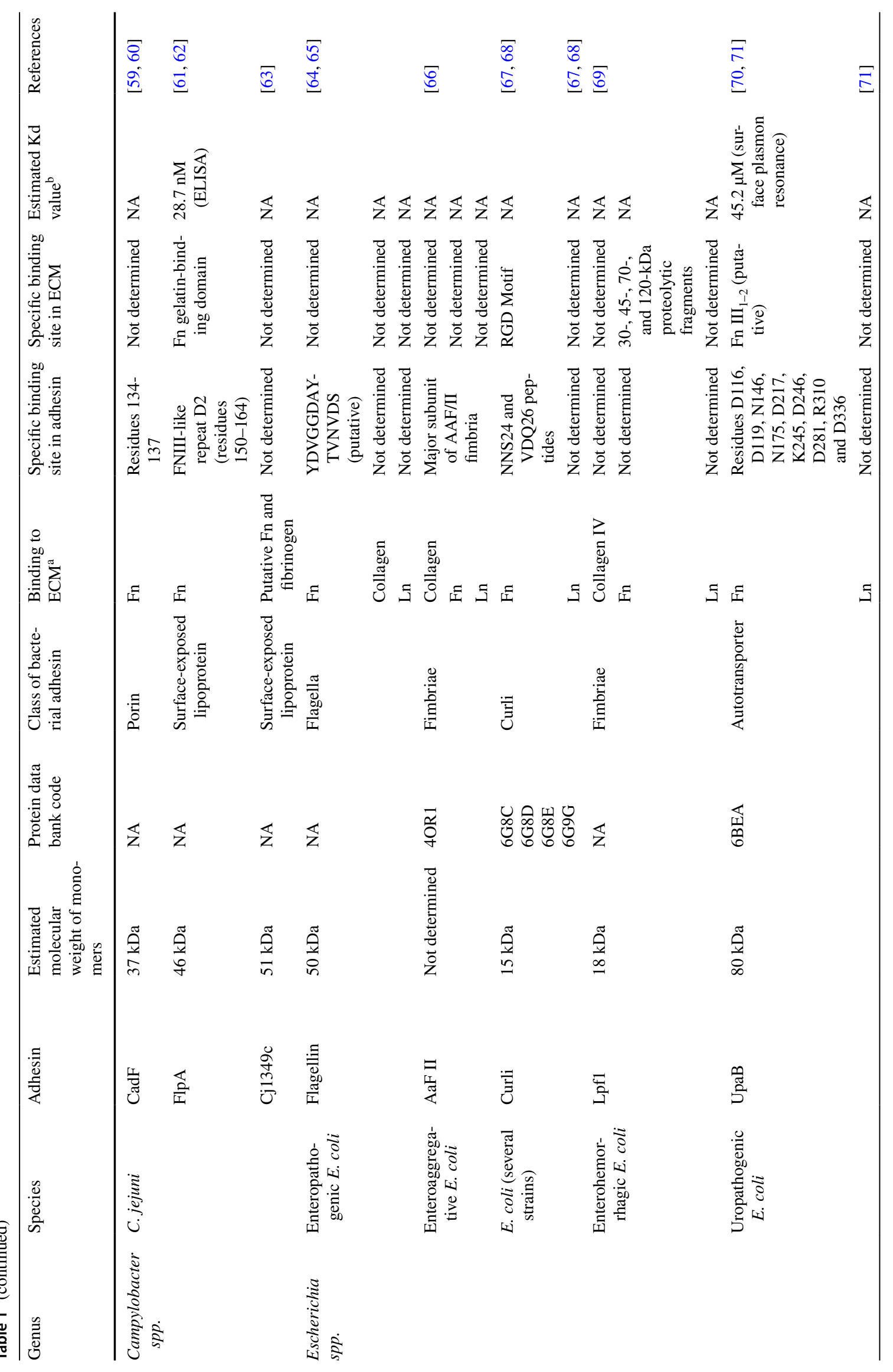




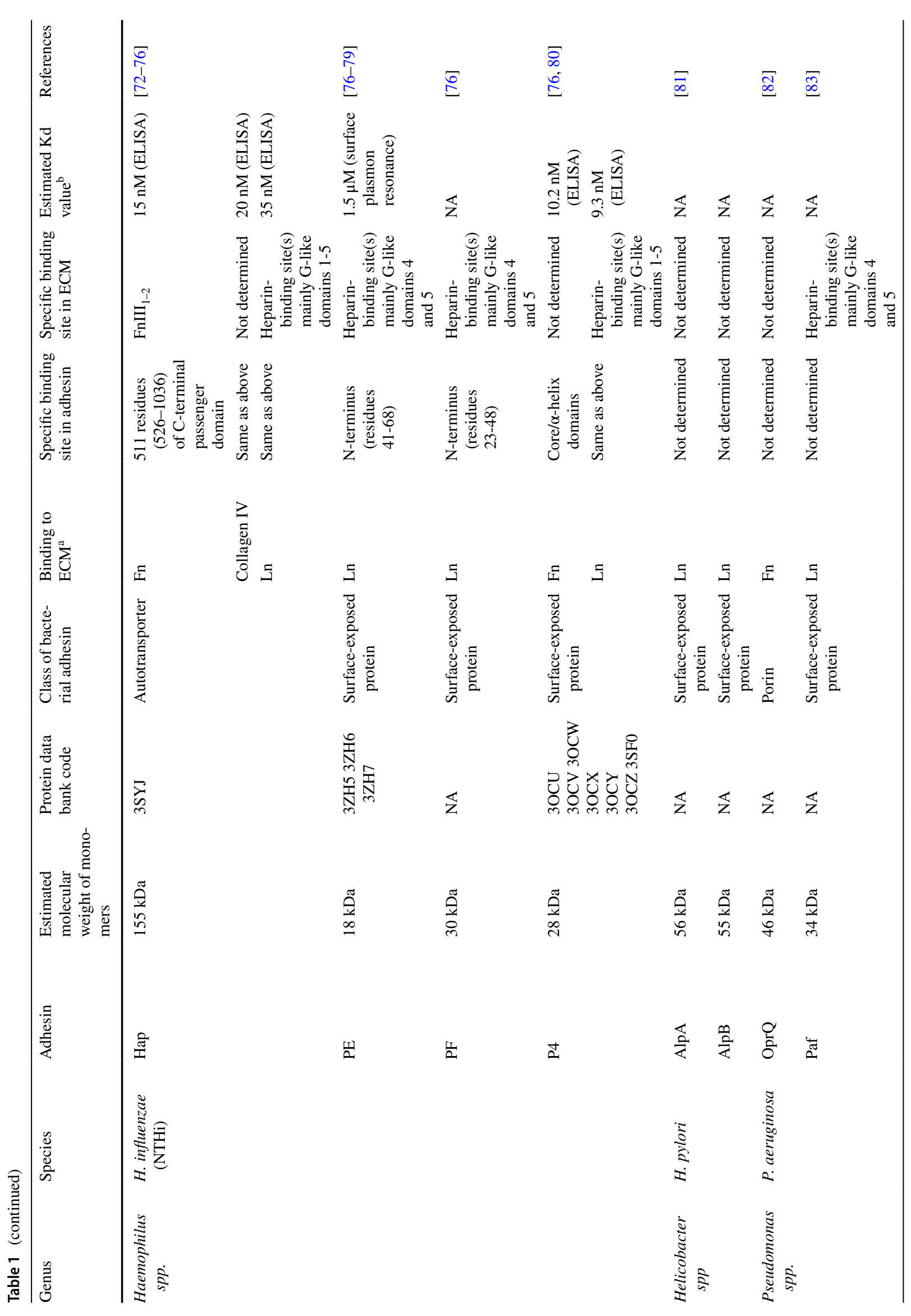




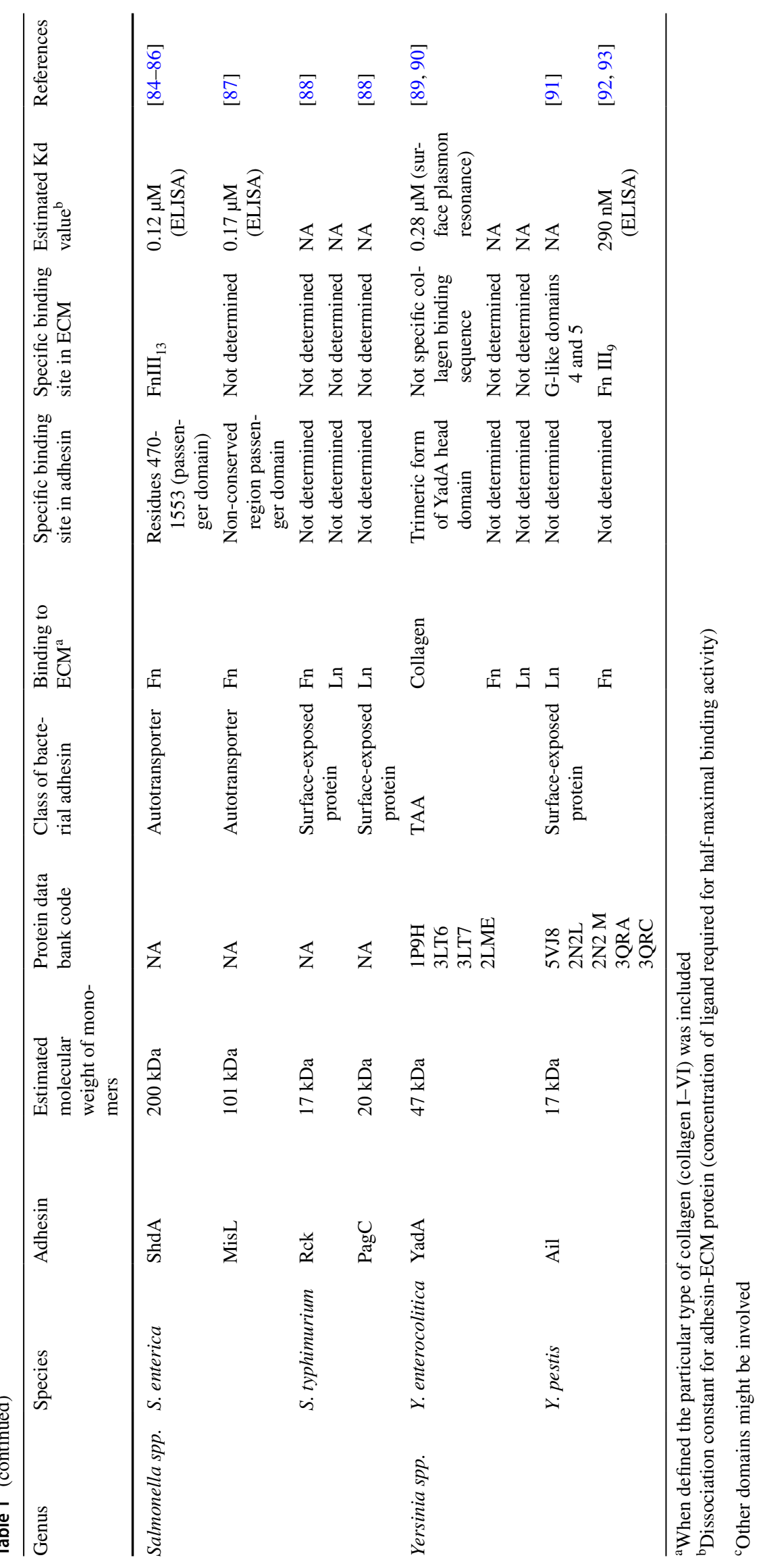


of wild-type strains and isogenic mutants, the mechanism of adhesion was found to be mediated by binding of BadA to ECM components (collagen III, Ln and Fn) under static and dynamic infection conditions [44, 98, 121]. Expression of truncated BadA-constructs (with deletions of specific subdomains) identified that the neck-stalk module of BadA is crucial for Fn-binding. This suggests that this neck-stalk module might mediate host cell adherence via interactions with, e.g., beta-1 integrins [45]. The head and a short part of the neck-stalk BadA module was found to be sufficient for collagen binding after expression of a truncated BadA hybrid in E. coli resulting in significantly higher adherence rates to endothelial cells than in E. coli controls [122]. These and other data demonstrate that the BadA protein is a major pathogenicity factor of $B$. henselae [44] and that the head and stalk domains of the protein have overlapping functions in the adhesion process [45].

Other bacterial surface proteins from $B$. henselae also show affinity to Fn. Pap31, a protein possibly involved in packaging or phage particle assembly, was described to be responsible for binding to immobilized Fn, specifically to the FnIII ${ }_{12-13}$ repeat module and to human umbilical vein endothelial cells (HUVECs) [46]. Additionally, Omp43, a porin protein [123], and Omp89 were identified as FnBPs after batch affinity-purification from OMPs binding to Fncoated wells [47].

Among the genus, there are other important TAAs detectable: Variably expressed outer membrane proteins (Vomps) are a group of proteins identified as crucial for the pathogenicity of $B$. quintana as shown in a macaque animal infection model [48]. Amidst the four Vomps A to D proteins, VompA-C contains collagen-binding motifs, but only VompA and VompC showed collagen IV binding in in vitro assays [48]. The importance of Vomps in the adherence process was confirmed by binding experiments using in vitro cell culture vials and in dynamic experiments using capillary flow chambers, where the interaction between $B$. quintana and HUVEC was diminished in the absence of Vomps [121]. Due to the similarities shown between the BadA and Vomps, it was initially thought that Vomps were FnBPs; nevertheless, binding assays between Vomp and Fn did not show affinity, and this exemplifies the complexity involved in the prediction of binding interaction [112].

In the case of $B$. bacilliformis, little research has been done regarding adhesins and their interaction with ECM proteins. The TAA Bartonella repeat protein (Brp), also called B. bacilliformis adhesin A (BbadA), shares common domains and structural features with the already identified TAAs, BadA, and Vomps. For this reason, it is speculated that $\mathrm{Brp} / \mathrm{BbadA}$ might be involved in similar biological processes including adhesion to host cells and ECM proteins [49, 124]. Additionally, hemin-binding proteins (Hbps) from B. bacilliformis are homologous to Pap31 from B. henselae.
Some possible interaction of Hbps with Fn might be speculated because of this reported similarity [49]. The role of flagellin in Fn-binding of B. bacilliformis has not been analyzed so far.

\section{Borrelia burgdorferi}

Borrelia burgdorferi is the causative agent of Lyme disease, one of the most common tick-borne diseases occurring in the Northern hemisphere. B. burgdorferi is a Gram-negative obligate extracellular spirochete, frequently found to be associated with its hosts' connective tissues [53]. The persistence of spirochetes in joints and connective tissue is essential for the incidence and severity of the infection [125]. Bacterial adhesion to host tissue is, therefore, a critical step for the initial process of infection and the capacity of spirochetes to disseminate to distant organs.

B. burgdorferi expresses at least 19 OMPs, many of which are known to bind to host cells and ECM components $[126,127]$. The BBK32 protein is a surface-exposed molecule first identified by its property to bind Fn [50]. Isogenic bbk32-deficient mutants showed an impaired ability to bind immobilized Fn and an attenuated adhesion to mouse fibroblast cells when compared to wild-type strains. Moreover, in a murine model of Lyme disease, mice infected with wildtype and isogenic mutants indicated a decreased infectivity of the $b b k 32$-deficient strains highlighting the importance of BBK32 for initial infection [128]. Recent research revealed a $70-\mathrm{kDa}$ N-terminal Fn region as the responsible element for BBK32 binding [129]. Regardless of the proven importance of the BBK32 protein in the infection process, the isogenic $b b k 32$-deficient mutants are still able to bind Fn with a reduced capacity suggesting that additional mechanisms for Fn-binding exist. RevA, another borrelial outer surface protein was discovered to bind to the $\mathrm{N}$-terminal Fn region in a comparable affinity as BBK32 based on their $K_{\mathrm{D}}$ values. RevA was also found to interact with Ln but in a lower affinity than BBK32 [57]. The RevA paralogous protein RevB was also identified as a FnBP after the evaluation of recombinant RevB protein in binding assays with Fn [57].

Spirochetes are often associated with connective tissues and collagen fibers in the infected mammalian hosts, suggesting the presence of adhesins for binding certain types of collagen. BBA33, a surface-exposed lipoprotein linked to bacterial virulence, has been proven to stick in high affinity to collagen type VI and to collagen type IV [52]. The affinity of Borrelia spp. to collagen fibers might also be related to the presence of collagen-associated proteoglycans such as decorin which is an abundant molecule in connective tissues. For instance, the decorin-binding proteins DbpA and DbpB display a strong affinity to decorin but lack binding affinity to collagen [130-133]. 
The first Ln-binding protein identified in B. burgdorferi was the OspE/F-related protein ErpX [55]. The interaction of this lipoprotein with Ln-containing host tissues favors migration through extracellular matrices with long-term colonization [56]. Borrelia membrane protein A (BmpA) is another LnBP. Binding of $\mathrm{Ln}$ with BmpA was obstructed upon the incubation of $\mathrm{Ln}$ with solubilized collagen. These competition assays localized the Ln-BmpA binding site at the collagen-binding region in Ln [53]. The BmpA paralogous proteins $\mathrm{BmpB}, \mathrm{BmpC}$, and $\mathrm{BmpD}$ have also been described as LnBPs [53]; all four paralogs are expressed during mammalian infections [134]. Of note, BmpA and $\mathrm{BmpB}$ are selectively expressed in joint tissues and, thus are involved in the genesis of Lyme arthritis [135].

Other borrelial adhesins comprise proteins displaying multi-functional properties; this is the case of complement regulator-acquiring surface protein $1(\mathrm{CspA})$ and $2(\mathrm{CspZ})$. Both proteins do not only bind to Fn and Ln but also to collagen type I, III, and IV with a stronger interaction in the case of CspA [54].

\section{Campylobacter jejuni}

Campylobacter jejuni is recognized as a common cause for bacterial gastroenteritis. Like other intestinal pathogens, the capacity to colonize the gastrointestinal tract by binding epithelial cells is a fundamental step during the initial phases of infection.

CadF from C. jejuni is an OMP described for the first time in 1997 after the observation of reduced binding to Fn in an isogenic strain lacking CadF expression [59]. Later research applying overlapping peptides of CadF identified a four-amino-acid sequence responsible for Fn-binding. Modifications in this sequence resulted in a recombinant $\mathrm{CadF}$ protein that significantly showed reduced Fn-binding and adherence to epithelial cells compared to the wild-type [60]. As a proof of concept, reduction in the internalization of $C$. jejuni into human intestinal epithelial cells was observed in a CadF mutant strain [136]. Other possible functions of CadF still remain unclear; post-translational proteolytic cleavages of the protein in clinical C. jejuni revealed that small fragments of CadF still bind Fn and are no longer recognized by the host humoral response [137].

The recently detected FnBP from $C$. jejuni is encoded by the gene $\mathrm{Cj} 1279 \mathrm{c}$; the protein was termed as Fn-like protein A (FlpA) because of the presence of three Fn type III-like repeats in its protein structure [63]. Due to the description of Fn-Fn interactions located in Fn type III domains [18], it was hypothesized that FlapA might be involved in Fnbinding activity [63]. FlapA was found to mediate bacterial attachment to host epithelial cells via Fn-binding [61], and this interaction was described to occur through the Fn gelatin-binding domain and the second Fn type III-like repeat from FlpA [62]. CadF and FlpA have probed to act together in cellular membrane rearrangements and epithelial cells invasion [138].

Other adhesins have also been identified in C. jejuni: for instance, $\mathrm{Cj} 1349 \mathrm{c}$ has been annotated as a putative $\mathrm{Fn} /$ fibrinogen-binding protein because of observed reduced binding in isogenic forms of the protein in vitro; however, its functional role in vivo is still unknown [63]. Additionally, adhesion of $C$. jejuni to collagen and Ln (only under high concentrations) has been reported via in vitro binding experiments using coated coverslips and OMP suspensions $[139,140]$.

\section{Escherichia coli}

Escherichia coli has been associated with diarrheal illness ranging from acute to long-lasting stages in developing and industrialized regions of the world. The worldwide spread of the bacteria has promoted the need to unravel the pathogenic mechanisms applied by this pathogen to colonize and infect intestinal cells. Several adhesins have been recognized for binding ECM proteins that are naturally present in epithelial cells; among them are flagella, aggregative adherence fimbriae (AaF), long-polar fimbriae (Lpf1), curli, and UpaB, highlighted for their multiple binding specificities.

The flagella of enteropathogenic and enterohemorrhagic $E$. coli contribute to host-colonization. Flagellin of enteropathogenic $E$. coli binds in a dose-dependent manner to collagen and to a lesser extent to Ln and Fn [64]. A more recent report demonstrated higher affinity of flagellin from an atypical enteropathogenic $E$. coli to cellular Fn, underlining the high variability of virulence strategies among this species [65]. Oppositely, flagellin of enterohemorrhagic $E$. coli has almost no selectivity for ECM proteins [64]; therefore, its contribution to host colonization might be related to other mechanisms.

In enteroaggregative $E$. coli, the AaF II protein contributes to the adherence to human intestinal tissue. Farfan et al. reported that enteroaggregative E. coli adhered more abundantly to surfaces precoated with Fn, Ln, and type IV collagen than a strain with a mutation in the AaF II major pilin gene, concluding that Fn-AaF II binding may contribute to colonization of the gastrointestinal tract [66]. Further research focused on the participation of $\alpha 5 \beta 1$ integrins in the Fn-mediated adherence of AaF II to intestinal cells. It was shown that enteroaggregative $E$. coli binds indirectly to integrin $\alpha 5 \beta 1$ (mediated by AaF II and Fn interaction), but remarkably it can also bind directly to integrin $\alpha 5 \beta 1$, presumably by the interaction of another so far uncharacterized adhesin [141].

Lpf1 protein from enterohemorrhagic E. coli has been associated with increased adherence to cultured cells (Caco2, HeLa-229) [142, 143]. In line with that observation, it 
was shown that mutations in the LP fimbrial operons of the lpf genes lead to a decreased colonization in animal models [144]. The adhesive properties of Lpf1 were described to be mediated via ECM protein binding, as inactivation of the $l p f A l$ gene significantly reduced the binding of $E$. coli mutants to Fn, Ln, and collagen IV [69].

Curli are thin surface fibers expressed by many pathogenic isolates of $E$. coli and other bacteria associated with severe infections in humans. Among clinical isolates of $E$. coli, most enterohemorrhagic, enterotoxigenic, and sepsisrelated strains express curli, in contrast to enteroinvasive and enteropathogenic strains, which lack curli expression. This difference in expression suggests a versatile role of curli fibers in pathogenicity [67, 145]. Curli fibers have been described as adhesins for their binding capacity to host molecules such as Fn and Ln. Remarkably, their ability to bind Fn has demonstrated to be an important factor for the internalization of bacteria in eukaryotic cells [145]. Recently, using a nanomechanical force-sensing approach, it was identified that curli and Fn formed multiple specific bonds with high tensile strength, resulting in tight $E$. coli binding [68].

$\mathrm{UpaB}$, an autotransporter of uropathogenic $E$. coli strains, is known to contribute to the colonization of the urinary tract and promotion of bacterial binding to the ECM proteins Fn, fibrinogen, and Ln, but not collagen (type I, II, III, IV, and V) [71]. Due to the observation of stronger affinity between UpaB and Fn, the molecular interaction between these two proteins was analyzed at a molecular level. Ten residues in UpaB (D116, D119, N146, N175, D217, K245, D246, D281, R310, and D336) demonstrated to be necessary to maintain the secondary structure of UpaB and to mediate Fn binding; from the Fn site, binding of UpaB was located at the FnIII region, most likely at the FnIII $_{1-2}$ [70]. Summarizing, the interaction between the two proteins involves the folding of a $\beta$-helix in UpaB presenting charged/polar residues which interact with charges on the FnIII domain [70].

\section{Haemophilus influenzae}

Haemophilus influenzae is often found as a commensal of the respiratory tract but also represents a common cause of respiratory tract infections and meningitis. The presence of a polysaccharide capsule classifies $H$. influenzae in encapsulated strains responsible for invasive disease and unencapsulated (nontypeable NTHi) strains found in mucosal infections in the upper and lower respiratory tract [146]. $H$. influenzae prefers binding to non-ciliated cells, areas with damaged epithelium and mucus present in the respiratory tract [147] via a number of OMPs that influence the process of adherence and colonization [148].

The Haemophilus adherence and penetration protein (Hap) is a classical autotransporter adhesin ubiquitously present among $H$. influenzae type b encapsulated and NTHi clinical strains. Hap promotes bacterial adherence to epithelial cells and mediates bacterial aggregation and microcolony formation by Hap-Hap interactions occurring between neighboring bacteria [73]. The passenger domain of the protein harbors a serine protease activity that directs autoproteolytic cleavage under dispersal and migration from the site of infection [147]. The mutation on the serine active site inhibits the release of Hap from the bacterial surface and results in increased adherence to epithelial cells [73]. Hap binds to Fn, collagen IV (but not collagen II), and Ln. Inhibition of bacterial binding to ECM proteins after the application of polyclonal antiserum against the passenger domain confirmed the importance of Hap in the infection process [72]. Hap was found to interact with the FnIII $_{1-2}$ region, a domain in Fn previously described as crucial for matrix assembly [18]. The interaction between Hap and FnIII ${ }_{1-2}$ might indicate that Hap is involved in the destabilization of the Fn matrix enabling the spread of $H$. influenzae through the submucosa to the basement membrane [75].

The surface lipoprotein Haemophilus protein E (PE) is a highly conserved protein among the Haemophilus spp. members [149]. PE induces the pro-inflammatory response during infection and promotes bacterial adherence and invasion through the binding of the N-terminal PE and the Ln globular domains [76, 79], which also happens with a simultaneous interaction of PE with vitronectin [78]. Moreover, Haemophilus protein $\mathrm{F}(\mathrm{PF})$, a ubiquitous protein of $\mathrm{H}$. influenzae, was described as a LnBP after the observation of reduced Ln-binding and human pulmonary epithelial cells' attachment in an isogenic hpf mutant [150].

The observation that $H$. influenzae mutants lacking expression of the known ECM-binding proteins (Hap, PE and $\mathrm{PF}$ ) still bind ECM proteins aroused the interest in other bacterial adhesins. To further study this, OMPs of $H$. influenzae were analyzed in regard to their ECM interactions. A 28-kDa protein, later identified as Haemophilus lipoprotein e (P4), was found binding to Ln, Fn, and vitronectin by a strong interaction (constant dissociation $\mathrm{Kd}: 9.26 \mathrm{nM}$, and $10.19 \mathrm{nM}$ and $16.51 \mathrm{nM}$, respectively) [80]. P4 is present in NTHi and encapsulated $H$. influenzae and was previously described as important for NAD uptake and hemin utilization [151, 152]. Interactome studies of Ln and NTHi strains gave a major description of interactions occurring between already known and novel LnBPs [76].

Although all adhesins (Hap, PE, PF and P4) exhibit binding capacities to ECM proteins, Hap has shown the highest binding capacity to Fn. In contrast, Ln binds almost equally well to all the bacterial adhesins [80]. It seems that not a single OMP of $H$. influenzae is responsible for bacterial adhesion to the host but a coordinated interaction between adhesins and host proteins. 


\section{Yersinia spp.}

The genus Yersinia harbors 17 different species but only three of them have been described to be pathogenic to humans ( $Y$. enterocolitica, $Y$. pseudotuberculosis, $Y$. pestis). Y. enterocolitica and Y. pseudotuberculosis are causative agents for a wide range of diseases associated with the consumption of contaminated food. Y. pestis is a zoonotic pathogen transmitted by fleas from one mammalian host to another. Three major adhesins have been described: the Yersinia adhesin A (YadA), invasin (Inv), and attachment invasion locus (Ail). These adhesins mediate attachment to host cells, either directly via binding integrins (as for invasin) $[153,154]$ or indirectly via ECM proteins. This attachment is a crucial prerequisite for injection of effector proteins (Yersinia outer proteins, Yops) via a type three secretion system and thus essential for a successful host cell invasion. Both YadA and Ail have been shown to bind Fn and Ln proteins [91], whereas only YadA may interact with collagen $[155,156]$.

YadA is by far the best described TAA. This protein is essential for virulence in $Y$. enterocolitica and is encoded by the pYV virulence plasmid. In contrast to $Y$. enterocolitica, Y. pseudotuberculosis does not require YadA for a successful colonization process $[157,158]$ and $Y$. pestis does not express the $y a d A$ gene due to a frameshift caused by a nucleotide deletion [159-161]. Among the manifold virulence traits associated with YadA, one very important role is the mediation of bacterial adhesion. YadA of Y. enterocolitica stably interacts with collagen types I, II, III, IV, V, and XI [155]. The YadA-collagen type I interaction has been studied in most detail due to the strong interactions. It was discovered that the trimeric form of the YadA head domain is essential for binding [90]. However, a specific sequence responsible for the interaction with collagen was not identified so far. Therefore, it is assumed that the binding motif is formed by a specific fold instead of a distinct peptide sequence [89]. Compared to most serotypes of $Y$. enterocolitica, the YadA of $Y$. pseudotuberculosis possesses an additional short stretch within its head domain. This region significantly determines the differential ECM-binding repertoire of the two Yersinia species. Actually, the deletion of this region abrogated Fn-binding but increased binding to collagen by four- to fivefold and significantly enhanced binding to Ln [158]. YadA of $Y$. enterocolitica also binds Fn and $\mathrm{Ln}$, however, with a significantly lower affinity compared to collagen and using a different binding region in the YadA molecule $[121,156]$. Y. enterocolitica strains of serotype O:9 contain a similar stretch and it was shown that this stretch is responsible for vitronectin binding [162]. The YadA-collagen interaction can even resist harsh conditions as incubation at $80{ }^{\circ} \mathrm{C}$ for $20 \mathrm{~min}, \mathrm{pH}$ values from 5.0 to 10.0 , proteolytic treatment, and incubation in $1 \mathrm{M}$ urea [163].
Ail is a $17-\mathrm{kDa}$ chromosomally encoded protein also associated with Yersinia virulence. Ail is present in Y. pestis, $Y$. enterocolitica, and Y. pseudotuberculosis, but the similarity between the protein sequences in the species is rather low [164]. Ail accomplishes an important activity in binding to ECM proteins (especially to $\mathrm{Ln}$ and Fn) with no detectable binding to collagen [91, 92]. Contrarily, in Y. pseudotuberculosis Ail lacks the conserved residues responsible for binding [165] but still accomplishes functions related to serum resistance. As Ail is a small-sized protein, its functions may be masked by LPS outer core and/or O-antigen and this has been shown already for $Y$. enterocolitica and $Y$. pseudotuberculosis. Therefore, Ail may only contribute to adhesion in strains expressing rough LPS, such as Y. pestis $[166,167]$.

\section{ECM interactions occurring in other Gram-negative bacteria}

For some genera of Gram-negative bacteria, the interactions occurring between adhesins and Fn, Ln or collagen are not critical for bacterial attachment, but the description of bacterial-host receptor occurrence is vital for understanding the orchestrated process of infection.

Salmonella enterica serotype Typhimurium expresses adhesins such as ShdA, MisL, and SadA, of which the last one is a TAA. ShdA and MisL are type Va autotransporter adhesins that have proved to contribute to intestinal colonization possibly by binding to Fn. The interaction of ShdA and Fn happens between the passenger domain and the FnIII 13 module, respectively [84, 85], while the interaction occurring between MisL and Fn has not been further described [87, 168]. Even though SadA shares structural similarities with YadA and BadA, current studies did not succeed in identifying any SadA-mediated interactions with ECM molecules. However, it was shown that SadA plays a role in biofilm formation and adhesion to human intestinal epithelial cells via a yet unknown mechanism [169]. Additionally, Rck and PagC, Salmonella-homologs of Ail of $Y$. pestis, have proved to induce bacterial binding to $\mathrm{Ln}$ and $\mathrm{Fn}$, when these adhesins are expressed in E. coli $[88,91]$.

Pseudomonas aeruginosa is an opportunistic pathogen affecting mainly immunocompromised patients and also has demonstrated affinity to ECM proteins (Fn and Ln). The outer membrane porin Q (OprQ), known to play an important role in membrane permeability, antibiotic resistance, and virulence, was later identified as a FnBP. Based on the observation that the expression of Fn is positively correlated with the degree of injury in affected tissue from lung epithelial cells [170], it seems to be possible that overexpression of Fn favors the adherence and colonization of $P$. aeruginosa in patients promoted by OprQ [82]. Moreover, Ln is a ubiquitously expressed ECM protein in the respiratory tract 
and is a highly important target for Paf (orthologue protein of $H$. influenzae protein $\mathrm{F}$ ) in $P$. aeruginosa also facilitating bacterial adherence [83].

Helicobacter pylori is the etiological agent of gastritis and malignant neoplasias, such as gastric cancer. The adherence to the gastric epithelium has been shown to enhance inflammation, yet only a few $H$. pylori adhesins have been paired with targets in host tissue. H. pylori was described as binding some ECM proteins with different affinity: vitronectin [171], collagen type IV, and Ln [172]. The binding capacity of $H$. pylori to collagen type IV and Ln was reduced when the bacteria was subjected to proteolytic enzymes, suggesting that the bacterial attachment to the basement membrane is mediated by bacterial surface proteins [172]. Later research demonstrated that $H$. pylori mutants lacking the adhesins AlpA and AlpB showed reduced binding to Ln, while expression of a plasmid containing the alpAB locus in E. coli conferred Ln-binding capacity. Surprisingly, such mutants did not show lesser inflammation capacity than the wild-type when gerbils were experimentally infected [81].

\section{Other interactions related to ECM binding proteins: degradation of ECM proteins by bacterial proteases}

In order to reach the host tissue, bacteria can make use of endogenous proteases to degrade the basement barrier protecting the ECM [4]. Presence of proteases has been more commonly described for fungi and parasites. However, the activity of a few bacterial proteases in the host ECM has also been observed. Examples are elastase and alkaline proteases produced by, e.g., $P$. aeruginosa; both enzymes target soluble Ln resulting in different cleavage products [173]. Another example is a chymotrypsin-like protease from Treponema denticola which allows bacterial invasion of the basement membrane after degradation of Ln, collagen IV, and fibrinogen [4, 174]. In H. pylori, proteases of the high-temperature requirement A (HtrA) family have ECM protein degradation activity. HtrA proteins cleave Fn in in vitro assays, suggesting implications of the secreted HtrA in the infection process and in the disruption of the epithelial barrier [175]. In Y. pseudotuberculosis, the Pla protein has protease activity degrading Ln and fibrin during the invasion of epithelial cells [176].

\section{Inhibition of bacterial adhesion as a possible therapeutic strategy}

The overwhelming increment of antibiotic resistance in many clinical bacterial isolates has stimulated the scientific and medical interest for the development of new approaches directed to combat serious infections. Many strategies designed against bacterial survival and growth pathways are already established; nevertheless, the selective pressure imposed by bactericidal promotes continuously the spread of resistant strains among clinical patients. This fact underlines the need for redirecting the focus to alternative therapeutic targets. Furthermore, the ambitious idea of blocking virulence factors associated with bacterial colonization and infection processes is an attractive strategy to possibly prevent infections, to attenuate already existing infections, and to promote the natural clearance of the pathogen $[3,29,39$, 177].

As stated before, adhesion plays a primordial role at distinct steps of the infection process; therefore, the attempt of targeting this interaction by the application of "antiadhesion"-therapeutics is not new and has been approached previously. One example is the type I pili adhesin of uropathogenic E. coli (FimH), which binds to mannosylated receptors on the surfaces of mammalian bladder epithelial cells. Anti-adhesion agents targeting FimH-mannosylated interaction have been observed either disrupting the adhesin protein directly $[178,179]$ or interfering with the binding by fitting the binding pocket of the host receptor in FimH (FimH antagonists) [180-182]. In murine models, administration of a FimH antagonist has proven to decrease bacterial colonization to similar levels as by antibiotic treatment suggesting an attractive alternative to classical antibiotics [183, 184]. However, it is worth mentioning that no antivirulence agent against uropathogenic $E$. coli has been tested in humans so far.

Alternatively, the observation of mucus secretion as a natural defense mechanism against enteropathogens guided the scientific interest in studies of a variety of mucin glycoproteins mimicking the glycosylation patterns present in epithelial surface receptors. Mucins bind and immobilize bacteria, favoring the bacterial clearance by discharging the mucus layer from the gastrointestinal tract [185]. Purified bovine mucin (Muc1) extracted from cow milk inhibited the binding in vitro of Gram-negative pathogens (E. coli and $S$. enterica serovar Typhimurium) to intestinal epithelial cells [186].

Peptide-based adhesion inhibitors represent another attractive approach to interfere with bacterial adherence. The feasibility of large-scale production and effectiveness in in vitro assays makes them an attractive target for an antiadhesive therapy approach. A promising example is represented by the multivalent adhesion molecule (MAM7), a bacterial surface protein involved in the attachment of a range of Gram-negative bacteria (enteropathogenic E. coli, Y. pseudotuberculosis and Vibrio spp.) to the host cell membrane receptors (Fn, phosphatidic acid) [187, 188]. An in vitro assay using bead-coupled MAM7 successfully reduced the cytotoxicity of host cells. It should be noted 
that this approach was not interfering with the bacterial-host receptor binding process directly, but via a bacterial-host receptor competition strategy after the pre-exposition of the host-receptor binding pocket to bead-coupled MAM7. The results brought to light a potential application of MAM7 as a prophylactic agent against multidrug-resistant bacterial pathogens [189, 190].

Moreover, elucidating the molecular mechanisms responsible for the anti-adhesive capacity of bioactive natural compounds from plants might give some insights about strategies to block bacteria-host interactions avoiding endogenous impact on cellular host signaling. Some examples are the anti-adhesion activity described for salvianolic acid B (SAB) against Neisseria meningitidis [191], the use of cranberry proanthocyanidins against uropathogenic E. coli $[192,193]$, and the identification of anti-adhesive peptides against a $H$. pylori FnBP obtained by the enzymatic hydrolysis of pea seeds Pisum sativum [194]. The presence of food components contrasting bacterial adhesion has been reviewed extensively [195].

Despite the promising future of anti-adhesion therapy, several considerations have to be made before the application of this concept to patients. First, the redundancy of the interaction between adhesins and cellular receptors represents a challenge. For instance, TAAs such as BadA and YadA show affinity to various ECM proteins [44, 156], while curli and flagellin from E. coli strains bind not only ECM proteins but also cellular receptors involved in immunity [196, 197]. Moreover, many pathogens such as P. aeruginosa express a wealth of adhesion and other virulence factors that may act in concert and/or redundantly. Blocking the function of a single adhesion molecule would, therefore, be an unsuccessful therapeutic strategy. Additionally, the design of high-affinity anti-ligands might be considered as a milestone for the treatment of bacterial infections. The similarity between pathogenic adhesins and extracellular protein domains, as the case of FlpA from C. jejuni and Fn type III domains [63], implies that interfering with pathogen attachment might compete with host signaling pathways leading to undesirable consequences [198]. Another drawback is the fact that adhesins are often expressed only at very distinct time points of the infection process, as shown for YadA and invasin of $Y$. enterocolitica [156, 199, 200]. Based on this, the successful application of anti-ligands for treatment (once they have been designed) will depend strongly on the time point when these compounds are administered to a patient.

In summary, multiple strategies for bacterial attachment to the host exist and they are highly regulated and orchestrated during the entire course of an infection [201]. Attempts to overcome the limitations of an anti-adhesin therapeutic strategy will thus require also a time-resolved and tissue-specific understanding of the host cell signaling events occurring during the infection process. Even so, and in the light of the global threat of emerging and spreading antibiotic-resistant pathogens, anti-adhesion and in a more general way anti-virulence therapies might be a worthwhile alternative to classical antibiotic treatment.

\section{Concluding remarks}

As we gain more and more insights into the interactions that occur during host cell adhesion, colonization, and the invasion processes of pathogenic bacteria, the complexity of these interactions becomes obvious. The evolution of adhesin structures and the redundancy for cellular targets suggest a dynamic interaction and adaptability to the particular conditions in host tissues. This creates a challenge for researchers aiming at the inhibition of host-pathogen interactions. Even though matrix-binding proteins have been studied for more than 40 years, it is still a long way to comprehensively understand the underlying molecular mechanisms important for the bacterium-host interplay. Because of the current limitations associated with the application of any anti-adhesion therapy, further efforts are necessary to better understand these interactions in the search for therapeutic alternatives to overcome the severe threat by multidrug resistant Gram-negative bacteria.

Acknowledgements This research was supported by the Viral and Bacterial Adhesin Network Training (ViBrANT) Program funded by the European Union's HORIZON 2020 Research and Innovation Program under the Marie Sklodowska-Curie Grant Agreement No 765042, by the Deutsche Forschungsgemeinschaft [DFG FOR 2251] and by the Robert Koch-Institute, Berlin, Germany (Bartonella consiliary laboratory, 1369-354). This article is published as part of the Special Issue on "Vibrant ITN".

Open Access This article is distributed under the terms of the Creative Commons Attribution 4.0 International License (http://creativeco mmons.org/licenses/by/4.0/), which permits unrestricted use, distribution, and reproduction in any medium, provided you give appropriate credit to the original author(s) and the source, provide a link to the Creative Commons license, and indicate if changes were made.

\section{References}

1. Chagnot C, Zorgani MA, Astruc T, Desvaux M (2013) Proteinaceous determinants of surface colonization in bacteria: bacterial adhesion and biofilm formation from a protein secretion perspective. Front Microbiol 4:1-26. https://doi.org/10.3389/fmicb .2013 .00303

2. Berne C, Ducret A, Hardy GG, Brun YV (2015) Adhesins involved in attachment to abiotic surfaces by Gram-negative bacteria. Microbiol Spectr 3:1-45. https://doi.org/10.1128/micro biolspec.MB-0018-2015

3. Stones D, Krachler A-M (2015) Fatal attraction: how bacterial adhesins affect host signaling and what we can learn from them. 
Int J Mol Sci 16:2626-2640. https://doi.org/10.3390/ijms160226 26

4. Singh B, Fleury C, Jalalvand F, Riesbeck K (2012) Human pathogens utilize host extracellular matrix proteins laminin and collagen for adhesion and invasion of the host. FEMS Microbiol Rev 36:1122-1180. https://doi.org/10.1111/j.1574-6976.2012.00340 .x

5. Kuusela P (1978) Fibronectin binds to Staphylococcus aureus. Nature 276:718-720. https://doi.org/10.1038/276718a0

6. Frantz C, Stewart KM, Weaver VM (2010) The extracellular matrix at a glance. J Cell Sci 123:4195-4200. https://doi. org/10.1242/jcs.023820

7. Khoshnoodi J, Pedchenko V, Hudson BG (2008) Mammalian collagen IV. Microsc Res Tech 71:357-370. https://doi. org/10.1002/jemt.20564

8. Fleury C, Serpentini A, Kypriotou M et al (2011) Characterization of a non-fibrillar-related collagen in the mollusc Haliotis tuberculata and its biological activity on human dermal fibroblasts. Mar Biotechnol 13:1003-1016. https://doi.org/10.1007/ s10126-011-9364-9

9. Kadler KE, Baldock C, Bella J, Boot-Handford RP (2007) Collagens at a glance. J Cell Sci 120:1955-1958. https://doi. org/10.1242/jcs.03453

10. Ricard-Blum S (2011) The collagen family. Cold Spring Harb Perspect Biol 3:a004978-a004978. https://doi.org/10.1101/ cshperspect.a004978

11. Lodish H, Berk A, Zipursky SL et al (2000) Molecular cell biology, 4th edn. Section 22.3, Collagen: the fibrous proteins of the matrix. W.H. Freeman, New York

12. Shaw LM, Olsen BR (1991) FACIT collagens: diverse molecular bridges in extracellular matrices. Trends Biochem Sci 16:191-194. https://doi.org/10.1016/0968-0004(91)90074-6

13. Canty EG, Kadler KE (2005) Procollagen trafficking, processing and fibrillogenesis. J Cell Sci 118:1341-1353. https://doi. org/10.1242/jcs.01731

14. Cho J, Mosher DF (2006) Role of fibronectin assembly in platelet thrombus formation. J Thromb Haemost 4:1461-1469. https ://doi.org/10.1111/j.1538-7836.2006.01943.x

15. Hynes RO (1990) Fibronectins. Springer, New York

16. Mao Y, Schwarzbauer JE (2005) Fibronectin fibrillogenesis, a cell-mediated matrix assembly process. Matrix Biol 24:389399. https://doi.org/10.1016/j.matbio.2005.06.008

17. Sottile J, Chandler J (2004) Fibronectin matrix turnover occurs through a caveolin-1-dependent process. Mol Biol Cell 16:757-768. https://doi.org/10.1091/mbc.e04-08-0672

18. Pankov R, Yamada K (2002) Fibronectin at a glance. J Cell Sci 115:3861-3863. https://doi.org/10.1242/jcs.00059

19. Tressel T, McCarthy JB, Calaycay J et al (1991) Human plasma fibronectin. Demonstration of structural differences between the A- and B-chains in the III CS region. Biochem J 274(Pt 3):731-738. https://doi.org/10.1042/bj2740731

20. Wilson CL, Schwarzbauer JE (1992) The alternatively spliced $\mathrm{V}$ region contributes to the differential incorporation of plasma and cellular fibronectins into fibrin clots. J Cell Biol 119:923-933

21. Henderson B, Nair S, Pallas J, Williams MA (2011) Fibronectin: a multidomain host adhesin targeted by bacterial fibronectinbinding proteins. FEMS Microbiol Rev 35:147-200. https://doi. org/10.1111/j.1574-6976.2010.00243.x

22. Hymes JP, Klaenhammer TR (2016) Stuck in the middle: fibronectin-binding proteins in Gram-positive bacteria. Front Microbiol 7:1504. https://doi.org/10.3389/fmicb.2016.01504

23. Raitman I, Huang ML, Williams SA et al (2018) Heparinfibronectin interactions in the development of extracellular matrix insolubility. Matrix Biol 67:107-122. https://doi. org/10.1016/j.matbio.2017.11.012
24. Schwarz-Linek U, Werner JM, Pickford AR et al (2003) Pathogenic bacteria attach to human fibronectin through a tandem $\beta$-zipper. Nature 423:177-181. https://doi.org/10.1038/natur e01589

25. Sottile J, Schwarzbauer J, Selegue J, Mosher DF (1991) Five type I modules of fibronectin form a functional unit that binds to fibroblasts and Staphylococcus aureus. J Biol Chem 266:12840-12843

26. Nakagami Y, Abe K, Nishiyama N, Matsuki N (2018) Laminin degradation by plasmin regulates long-term potentiation. J Neurosci 20:2003-2010. https://doi.org/10.1523/jneurosci.20-0502003.2000

27. Ogura Y, Matsunaga Y, Nishiyama T, Amano S (2008) Plasmin induces degradation and dysfunction of laminin 332 (laminin 5) and impaired assembly of basement membrane at the dermalepidermal junction. Br J Dermatol 159:49-60. https://doi.org/1 0.1111/j.1365-2133.2008.08576.x

28. Keller B, Mühlenkamp M, Deuschle E et al (2015) Yersinia enterocolitica exploits different pathways to accomplish adhesion and toxin injection into host cells. Cell Microbiol 17:1179-1204. https://doi.org/10.1111/cmi.12429

29. Kline KA, Fälker S, Dahlberg S et al (2009) Bacterial adhesins in host-microbe interactions. Cell Host Microbe 5:580-592. https ://doi.org/10.1016/j.chom.2009.05.011

30. Linke D, Goldman A (2011) Bacterial adhesion. Springer, Dordrecht

31. Leo JC, Grin I, Linke D (2012) Type V secretion: Mechanism(S) of autotransport through the bacterial outer membrane. Philos Trans R Soc B Biol Sci 367:1088-1101. https://doi.org/10.1098/ rstb.2011.0208

32. Pavlova O, Peterson JH, Ieva R, Bernstein HD (2013) Mechanistic link between $\beta$ barrel assembly and the initiation of autotransporter secretion. Proc Natl Acad Sci USA. https://doi. org/10.1073/pnas.1219076110

33. Lehr U, Schütz M, Oberhettinger P et al (2010) C-terminal amino acid residues of the trimeric autotransporter adhesin YadA of Yersinia enterocolitica are decisive for its recognition and assembly by BamA. Mol Microbiol 78:932-946. https://doi.org/10.11 11/j.1365-2958.2010.07377.x

34. Albenne C, Ieva R (2017) Job contenders: roles of the $\beta$-barrel assembly machinery and the translocation and assembly module in autotransporter secretion. Mol Microbiol 106:505-517. https ://doi.org/10.1111/mmi.13832

35. Linke D, Riess T, Autenrieth IB et al (2006) Trimeric autotransporter adhesins: variable structure, common function. Trends Microbiol 14:264-270. https://doi.org/10.1016/j.tim.2006.04.005

36. Wells TJ, Tree JJ, Ulett GC, Schembri MA (2007) Autotransporter proteins: novel targets at the bacterial cell surface. FEMS Microbiol Lett 274:163-172. https://doi.org/10.111 1/j.1574-6968.2007.00833.x

37. Gilmore RD, Bellville TM, Sviat SL, Steven L, Michael M (2004) The Bartonella vinsonii subsp. arupensis immunodominant surface antigen BrpA Gene, encoding a 382-Kilodalton protein composed of repetitive sequences, is a member of a multigene family conserved among Bartonella species. Infect Immun 73:3128-3136. https://doi.org/10.1128/IAI.73.5.3128-3136.2005

38. Scherer DC, Deburon-Connors I, Minnick MF (1993) Characterization of Bartonella bacilliformis flagella and effect of antiflagellin antibodies on invasion of human erythrocytes. Infect Immun 61:4962-4971

39. Pizarro-Cerdá J, Cossart P (2006) Bacterial adhesion and entry into host cells. Cell 124:715-727. https://doi.org/10.1016/j. cell.2006.02.012

40. Bentancor LV, Camacho-Peiro A, Bozkurt-Guzel C et al (2012) Identification of Ata, a multifunctional trimeric autotransporter 
of Acinetobacter baumannii. J Bacteriol 194:3950-3960. https ://doi.org/10.1128/JB.06769-11

41. Bentancor LV, Routray A, Bozkurt-Guzel C et al (2012) Evaluation of the trimeric autotransporter Ata as a vaccine candidate against Acinetobacter baumannii infections. Infect Immun 80:3381-3388. https://doi.org/10.1128/IAI.06096-11

42. Smani Y, McConnell MJ, Pachón J (2012) Role of fibronectin in the adhesion of Acinetobacter baumannii to host cells. PLoS One 7:e33073. https://doi.org/10.1371/journal.pone.0033073

43. Smani Y, Dominguez-Herrera J, Pachon J (2013) Association of the outer membrane protein Omp33 with fitness and virulence of Acinetobacter baumannii. J Infect Dis 208:1561-1570. https ://doi.org/10.1093/infdis/jit386

44. Riess T, Andersson SGE, Lupas A et al (2004) Bartonella adhesin A mediates a proangiogenic host cell response. J Exp Med 200:1267-1278. https://doi.org/10.1084/jem.20040500

45. Kaiser PO, Riess T, Wagner CL et al (2008) The head of Bartonella adhesin A is crucial for host cell interaction of Bartonella henselae. Cell Microbiol 10:2223-2234. https://doi.org/10.111 1/j.1462-5822.2008.01201.x

46. Dabo SM, Confer AW, Anderson BE, Gupta S (2006) Bartonella henselae Pap31, an extracellular matrix adhesin, binds the fibronectin repeat III13 module. Infect Immun 74:2513-2521. https://doi.org/10.1128/IAI.74.5.2513-2521.2006

47. Dabo SM, Confer AW, Saliki JT, Anderson BE (2006) Binding of Bartonella henselae to extracellular molecules: Identification of potential adhesins. Microb Pathog 41:10-20. https://doi. org/10.1016/j.micpath.2006.04.003

48. Zhang P, Chomel BB, Schau MK et al (2004) A family of variably expressed outer-membrane proteins (Vomp) mediates adhesion and autoaggregation in Bartonella quintana. Proc Natl Acad Sci 101:13630-13635. https://doi.org/10.1073/pnas.0405284101

49. Henriquez-Camacho C, Ventosilla P, Minnick MF et al (2015) Proteins of Bartonella bacilliformis: candidates for vaccine development. Int J Pept 2015:1-5. https://doi.org/10.1155/2015/70278 4

50. Probert WS, Johnson BJB (1998) Identification of a $47 \mathrm{kDa}$ fibronectin-binding protein expressed by Borrelia burgdorferi isolate B31. Mol Microbiol 30:1003-1015. https://doi.org/10.1 046/j.1365-2958.1998.01127.x

51. Kim JH, Singvall J, Schwarz-Linek U et al (2004) BBK32, a fibronectin binding MSCRAMM from Borrelia burgdorferi, contains a disordered region that undergoes a conformational change on ligand binding. J Biol Chem 279:41706-41714. https ://doi.org/10.1074/jbc.M401691200

52. Zhi H, Weening EH, Barbu EM et al (2015) The BBA33 lipoprotein binds collagen and impacts Borrelia burgdorferi pathogenesis. Mol Microbiol 96:68-83. https://doi.org/10.1111/mmi.12921

53. Verma A, Brissette CA, Bowman A, Stevenson B (2009) Borrelia burgdorferi $\mathrm{BmpA}$ is a laminin-binding protein. Infect Immun 77:4940-4946. https://doi.org/10.1128/IAI.01420-08

54. Hallström T, Haupt K, Kraiczy P et al (2010) Complement regulator-acquiring surface protein 1 of Borrelia burgdorferi binds to human bone morphogenic protein 2, several extracellular matrix proteins, and plasminogen. J Infect Dis 202:490-498. https://doi. org/10.1086/653825

55. Brissette CA, Verma A, Bowman A et al (2009) The Borrelia burgdorferi outer-surface protein ErpX binds mammalian laminin. Microbiology 155:863-872. https://doi.org/10.1099/ mic.0.024604-0

56. Brissette CA, Cooley AE, Burns LH et al (2008) Lyme borreliosis spirochete Erp proteins, their known host ligands, and potential roles in mammalian infection. Int J Med Microbiol 298:257-267. https://doi.org/10.1016/j.ijmm.2007.09.004
57. Brissette CA, Bykowski T, Cooley AE et al (2009) Borrelia burgdorferi RevA antigen binds host fibronectin. Infect Immun 77:2802-2812. https://doi.org/10.1128/IAI.00227-09

58. Brissette CA, Rossmann E, Bowman A et al (2010) The Borrelial fibronectin-binding protein RevA is an early antigen of human Lyme disease. Clin Vaccine Immunol 17:274-280. https://doi. org/10.1128/CVI.00437-09

59. Konkel ME, Garvis SG, Tipton SL et al (1997) Identification and molecular cloning of a gene encoding a fibronectin- binding protein (CadF) from Campylobacter jejuni. Mol Microbiol 24:953-963. https://doi.org/10.1046/j.1365-2958.1997.40317 71.x

60. Konkel ME, Christensen JE, Keech AM et al (2005) Identification of a fibronectin-binding domain within the Campylobacter jejuni CadF protein. Mol Microbiol 57:1022-1035. https://doi. org/10.1111/j.1365-2958.2005.04744.x

61. Konkel ME, Larson CL, Flanagan RC (2010) Campylobacter jejuni FlpA binds fibronectin and is required for maximal host cell adherence. J Bacteriol 192:68-76. https://doi.org/10.1128/ JB.00969-09

62. Larson CL, Samuelson DR, Eucker TP et al (2013) The fibronectin-binding motif within flpa facilitates Campylobacter jejuni adherence to host cell and activation of host cell signaling. Emerg Microbes Infect 2:1-12. https://doi.org/10.1038/emi.2013.65

63. Flanagan RC, Neal-McKinney JM, Dhillon AS et al (2009) Examination of Campylobacter jejuni putative adhesins leads to the identification of a new protein, designated FlpA, required for chicken colonization. Infect Immun 77:2399-2407. https:// doi.org/10.1128/IAI.01266-08

64. Erdem AL, Avelino F, Xicohtencatl-Cortes J, Giron JA (2007) Host protein binding and adhesive properties of $\mathrm{H} 6$ and $\mathrm{H} 7$ flagella of attaching and effacing Escherichia coli. J Bacteriol 189:7426-7435. https://doi.org/10.1128/JB.00464-07

65. Moraes CTP, Polatto JM, Rossato SS et al (2015) Flagellin and GroEL mediates in vitro binding of an atypical enteropathogenic Escherichia coli to cellular fibronectin. BMC Microbiol 15:1-10. https://doi.org/10.1186/s12866-015-0612-4

66. Farfan MJ, Inman KG, Nataro JP (2008) The major pilin subunit of the AAF/II fimbriae from enteroaggregative Escherichia coli mediates binding to extracellular matrix proteins. Infect Immun 76:4378-4384. https://doi.org/10.1128/IAI.00439-08

67. Olsén A, Herwald H, Wikström $M$ et al (2002) Identification of two protein-binding and functional regions of curli, a surface organelle and virulence determinant of Escherichia coli. J Biol Chem 277:34568-34572. https://doi.org/10.1074/jbc.M2063 53200

68. Oh YJ, Hubauer-Brenner M, Gruber HJ et al (2016) Curli mediate bacterial adhesion to fibronectin via tensile multiple bonds. Sci Rep 6:33909. https://doi.org/10.1038/srep33909

69. Farfan MJ, Cantero L, Vidal R et al (2011) Long polar fimbriae of enterohemorrhagic Escherichia coli O157:H7 bind to extracellular matrix proteins. Infect Immun 79:3744-3750. https://doi. org/10.1128/IAI.05317-11

70. Paxman JJ, Lo AW, Sullivan MJ et al (2019) Unique structural features of a bacterial autotransporter adhesin suggest mechanisms for interaction with host macromolecules. Nat Commun 10:1967. https://doi.org/10.1038/s41467-019-09814-6

71. Allsopp LP, Beloin C, Ulett GC et al (2012) Molecular characterization of UpaB and UpaC, two new autotransporter proteins of uropathogenic Escherichia coli CFT073. Infect Immun 80:321-332. https://doi.org/10.1128/IAI.05322-11

72. Fink DL, Green BA, St Geme JW (2002) The Haemophilus influenzae Hap autotransporter binds to fibronectin, laminin, and collagen IV. Infect Immun 70:4902-4907. https://doi.org/10.1128/ iai.70.9.4902-4907.2002 
73. Fink DL, Buscher AZ, Green B et al (2003) The Haemophilus influenzae Hap autotransporter mediates microcolony formation and adherence to epithelial cells and extracellular matrix via binding regions in the $\mathrm{C}$-terminal end of the passenger domain. Cell Microbiol 5:175-186. https://doi.org/10.104 6/j.1462-5822.2003.00266.x

74. Meng G, Spahich N, Kenjale R et al (2011) Crystal structure of the Haemophilus influenzae Hap adhesin reveals an intercellular oligomerization mechanism for bacterial aggregation. EMBO J 30:3864-3874. https://doi.org/10.1038/emboj.2011.279

75. Spahich NA, Kenjale R, McCann J et al (2014) Structural determinants of the interaction between the Haemophilus influenzae Hap autotransporter and fibronectin. Microbiology 160:11821190. https://doi.org/10.1099/mic.0.077784-0

76. Su Y-C, Mattsson E, Singh B et al (2019) The laminin interactome: a multifactorial laminin-binding strategy by nontypeable Haemophilus influenzae for effective adherence and colonization. J Infect Dis 220:1049-1060. https://doi.org/10.1093/infdi s/jiz217

77. Singh B, Al Jubair T, Förnvik K et al (2012) Crystallization and X-ray diffraction analysis of a novel surface-adhesin protein: protein E from Haemophilus influenzae. Acta Crystallogr Sect F Struct Biol Cryst Commun 68:222-226. https:// doi.org/10.1107/S1744309111055503

78. Singh B, Al-Jubair T, Mörgelin M et al (2013) The unique structure of Haemophilus influenzae protein E reveals multiple binding sites for host factors. Infect Immun 81:801-814. https ://doi.org/10.1128/IAI.01111-12

79. Hallström T, Singh B, Resman F et al (2011) Haemophilus influenzae protein $\mathrm{E}$ binds to the extracellular matrix by concurrently interacting with laminin and vitronectin. J Infect Dis 204:1065-1074. https://doi.org/10.1093/infdis/jir459

80. Su Y-C, Mukherjee O, Singh B et al (2016) Haemophilus influenzae $\mathrm{P} 4$ interacts with extracellular matrix proteins promoting adhesion and serum resistance. J Infect Dis 213:314-323. https ://doi.org/10.1093/infdis/jiv374

81. Senkovich OA, Yin J, Ekshyyan V et al (2011) Helicobacter pylori AlpA and AlpB bind host laminin and influence gastric inflammation in gerbils. Infect Immun 79:3106-3116. https:// doi.org/10.1128/IAI.01275-10

82. Arhin A, Boucher C (2010) The outer membrane protein OprQ and adherence of Pseudomonas aeruginosa to human fibronectin. Microbiology 156:1415-1423. https://doi.org/10.1099/ mic.0.033472-0

83. Su Y-C, Halang P, Fleury C et al (2017) Haemophilus protein $\mathrm{F}$ orthologs of pathogens infecting the airways: exploiting host laminin at heparin-binding sites for maximal adherence to epithelial cells. J Infect Dis 216:1303-1307. https://doi. org/10.1093/infdis/jix467

84. Kingsley RA, Santos RL, Keestra AM et al (2002) Salmonella enterica serotype Typhimurium ShdA is an outer membrane fibronectin-binding protein that is expressed in the intestine. Mol Microbiol 43:895-905. https://doi.org/10.104 6/j.1365-2958.2002.02805.x

85. Kingsley RA, Abi Ghanem D, Puebla-Osorio N et al (2004) Fibronectin binding to the Salmonella enterica serotype Typhimurium ShdA autotransporter protein is inhibited by a monoclonal antibody recognizing the A3 repeat. J Bacteriol 186:4931-4939. https://doi.org/10.1128/ JB.186.15.4931-4939.2004

86. Kingsley RA, Keestra AM, De Zoete MR, Bäumler AJ (2004) The ShdA adhesin binds to the cationic cradle of the fibronectin 13FnIII repeat module: evidence for molecular mimicry of heparin binding. Mol Microbiol 52:345-355. https://doi.org/10.111 1/j.1365-2958.2004.03995.x
87. Dorsey CW, Laarakker MC, Humphries AD et al (2005) Salmonella enterica serotype Typhimurium MisL is an intestinal colonization factor that binds fibronectin. Mol Microbiol 57:196-211. https://doi.org/10.1111/j.1365-2958.2005.04666.x

88. Crago AM, Koronakis V (1999) Binding of extracellular matrix laminin to Escherichia coli expressing the Salmonella outer membrane proteins Rck and PagC. FEMS Microbiol Lett 176:495-501. https://doi.org/10.1111/j.1574-6968.1999.tb137 03. $\mathrm{x}$

89. Leo JC, Elovaara H, Brodsky B et al (2008) The Yersinia adhesin YadA binds to a collagenous triple-helical conformation but without sequence specificity. Protein Eng Des Sel 21:475-484. https://doi.org/10.1093/protein/gzn025

90. Nummelin H, Merckel MC, Leo JC et al (2004) The Yersinia adhesin YadA collagen-binding domain structure is a novel left-handed parallel $\beta$-roll. EMBO J 23:701-711. https://doi. org/10.1038/sj.emboj.7600100

91. Yamashita S, Lukacik P, Barnard TJ et al (2011) Structural insights into Ail-mediated adhesion in Yersinia pestis. Structure 19:1672-1682. https://doi.org/10.1016/j.str.2011.08.010

92. Tsang TM, Annis DS, Kronshage M et al (2012) Ail protein binds ninth type III fibronectin repeat (9 FNIII) within central $120-\mathrm{kDa}$ region of fibronectin to facilitate cell binding by Yersinia pestis. J Biol Chem 287:16759-16767. https://doi. org/10.1074/jbc.M112.358978

93. Tsang TM, Felek S, Krukonis ES (2010) Ail binding to fibronectin facilitates Yersinia pestis binding to host cells and Yop delivery. Infect Immun 78:3358-3368. https://doi. org/10.1128/IAI.00238-10

94. Peleg AY, Seifert H, Paterson DL (2008) Acinetobacter baumannii: Emergence of a successful pathogen. Clin Microbiol Rev 21:538-582. https://doi.org/10.1128/CMR.00058-07

95. Shlaes DM, Bradford PA (2018) Antibiotics-from there to where?: how the antibiotic miracle is threatened by resistance and a broken market and what we can do about it. Pathog Immun 3:19. https://doi.org/10.20411/pai.v3i1.231

96. KÖLjalg S, Vuopio-Varkila J, LyytikÄInen O et al (1996) Cell surface properties of Acinetobacter baumannii. APMIS 104:659-665. https://doi.org/10.1111/j.1699-0463.1996.tb049 26.x

97. Morris FC, Dexter C, Kostoulias X et al (2019) The mechanisms of disease caused by Acinetobacter baumannii. Front Microbiol 10:1601. https://doi.org/10.3389/fmicb.2019.01601

98. Weidensdorfer M, Chae JI, Makobe C et al (2016) Analysis of endothelial adherence of Bartonella henselae and Acinetobacter baumannii using a dynamic human ex vivo infection model. Infect Immun 84:711-722. https://doi.org/10.1128/IAI.01502 $-15$

99. Weidensdorfer M, Ishikawa M, Hori K et al (2019) The Acinetobacter trimeric autotransporter adhesin Ata controls key virulence traits of Acinetobacter baumannii. Virulence 10:68-81. https://doi.org/10.1080/21505594.2018.1558693

100. Jyothisri K, Deepak V, Rajeswari MR (1999) Purification and characterization of a major $40 \mathrm{kDa}$ outer membrane protein of Acinetobacter baumannii. FEBS Lett 443:57-60. https://doi. org/10.1016/s0014-5793(98)01679-2

101. Ahmad TA, Tawfik DM, Sheweita SA et al (2016) Development of immunization trials against Acinetobacter baumannii. Trials Vaccinol 5:53-60. https://doi.org/10.1016/J.TRIVA C.2016.03.001

102. Ansari H, Tahmasebi-Birgani M, Bijanzadeh M, et al. (2019) Study of the immunogenicity of outer membrane protein A (ompA) gene from Acinetobacter baumannii as DNA vaccine candidate in vivo. Iran J Basic Med Sci 22:669-675.https://doi. org/10.22038/ijbms.2019.30799.7427 
103. Choi CH, Lee EY, Lee YC et al (2005) Outer membrane protein 38 of Acinetobacter baumannii localizes to the mitochondria and induces apoptosis of epithelial cells. Cell Microbiol 7:1127-1138. https://doi.org/10.1111/j.1462-5822.2005.00538.x

104. Vila-Farrés X, Parra-Millán R, Sánchez-Encinales V et al (2017) Combating virulence of Gram-negative bacilli by OmpA inhibition. Sci Rep 7:14683. https://doi.org/10.1038/s41598-01714972-y

105. Jahangiri A, Rasooli I, Owlia P et al (2018) An integrative in silico approach to the structure of Omp33-36 in Acinetobacter baumannii. Comput Biol Chem 72:77-86. https://doi.org/10.1016/J. COMPBIOLCHEM.2018.01.003

106. Abdollahi S, Rasooli I, Mousavi Gargari SL (2018) An in silico structural and physicochemical characterization of TonB-dependent copper receptor in A. baumannii. Microb Pathog 118:18-31. https://doi.org/10.1016/J.MICPATH.2018.03.009

107. Eicher SC, Dehio C (2012) Bartonella entry mechanisms into mammalian host cells. Cell Microbiol 14:1166-1173. https://doi. org/10.1111/j.1462-5822.2012.01806.x

108. Dorsey K, Breitschwerdt E (1995) Intraerythrocytic presence of Bartonella henselae. J Clin Microbiol 33:1655-1656

109. Mehock JR, Greene CE, Gherardini FC et al (1998) Bartonella henselae invasion of feline erythrocytes in vitro. Infect Immun 66:3462-3466

110. Hill EM, Raji A, Valenzuela MS et al (1992) Adhesion to and invasion of cultured human cells by Bartonella bacilliformis. Infect Immun 60:4051-4058

111. Batterman HJ, Peek JA, Loutit JS et al (1995) Bartonella henselae and Bartonella quintana adherence to and entry into cultured human epithelial cells. Infect Immun 63:4553-4556

112. Schulte B, Linke D, Klumpp S et al (2006) Bartonella quintana variably expressed outer membrane proteins mediate vascular endothelial growth factor secretion but not host cell adherence. Infect Immun 74:5003-5013. https://doi.org/10.1128/IAI.00663 $-06$

113. Truttmann MC, Rhomberg TA, Dehio C (2011) Combined action of the type IV secretion effector proteins BepC and BepF promotes invasome formation of Bartonella henselae on endothelial and epithelial cells. Cell Microbiol 13:284-299. https://doi.org/ 10.1111/j.1462-5822.2010.01535.x

114. Musso T, Badolato R, Ravarino D et al (2001) Interaction of Bartonella henselae with the murine macrophage cell line J774: infection and proinflammatory response. Infect Immun 69:59745980. https://doi.org/10.1128/IAI.69.10.5974-5980.2001

115. Resto-Ruiz SI, Schmiederer M, Sweger D et al (2002) Induction of a potential paracrine angiogenic loop between human THP-1 macrophages and human microvascular endothelial cells during Bartonella henselae infection. Infect Immun 70:4564-4570. https ://doi.org/10.1128/IAI.70.8.4564-4570.2002

116. Vermi W, Facchetti F, Riboldi E et al (2006) Role of dendritic cell-derived CXCL13 in the pathogenesis of Bartonella henselae B-rich granuloma. Am Soc Hematol 107:454-462. https://doi. org/10.1182/blood-2005-04-1342

117. Rodrick D, Dillon B, Dexter M et al (2004) Culture-negative endocarditis due to Houston complex Bartonella henselae acquired in Noumea, New Caledonia. J Clin Microbiol 42:18461848. https://doi.org/10.1128/JCM.42.4.1846-1848.2004

118. Fournier P-E, Lelievre H, Eykyn SJ et al (2001) Epidemiologic and clinical characteristics of Bartonella quintana and Bartonella henselae endocarditis. Medicine (Baltimore) 80:245-251. https://doi.org/10.1097/00005792-200107000-00003

119. Noopetch P, Ponpinit T, Suankratay C (2018) Bartonella henselae infective endocarditis with dissemination: a case report and literature review in Southeast Asia. IDCases 13:1-4. https://doi. org/10.1016/j.idcr.2018.e00441
120. Holland TL, Baddour LM, Bayer AS et al (2016) Infective endocarditis. Nat Rev Dis Prim 2:16059. https://doi.org/10.1038/ nrdp.2016.59

121. Müller NF, Kaiser PO, Linke D et al (2011) Trimeric autotransporter adhesin-dependent adherence of Bartonella henselae, Bartonella quintana, and Yersinia enterocolitica to matrix components and endothelial cells under static and dynamic flow conditions. Infect Immun 79:2544-2553. https://doi.org/10.1128/ IAI.01309-10

122. Schmidgen T, Kaiser PO, Ballhorn W et al (2014) Heterologous expression of Bartonella adhesin A in Escherichia coli by exchange of trimeric autotransporter adhesin domains results in enhanced adhesion properties and a pathogenic phenotype. J Bacteriol 196:2155-2165. https://doi.org/10.1128/JB.01461-13

123. Kang J-G, Lee H-W, Ko S, Chae J-S (2018) Comparative proteomic analysis of outer membrane protein 43 (omp 43)-deficient Bartonella henselae. J Vet Sci 19:59. https://doi.org/10.4142/ jvs.2018.19.1.59

124. Kaiser PO, Riess T, O'Rourke F et al (2011) Bartonella spp.: Throwing light on uncommon human infections. Int J Med Microbiol 301:7-15. https://doi.org/10.1016/j.ijmm.2010.06.004

125. Brown EL, Wooten RM, Johnson BJB et al (2001) Resistance to Lyme disease in decorin-deficient mice. J Clin Invest 107:845852. https://doi.org/10.1172/JCI11692

126. Brissette CA, Gaultney RA (2014) That's my story, and I'm sticking to it-an update on B. burgdorferi adhesins. Front Cell Infect Microbiol 4:1-13. https://doi.org/10.3389/fcimb.2014.00041

127. Caine JA, Coburn J (2016) Multifunctional and redundant roles of Borrelia burgdorferi outer surface proteins in tissue adhesion, colonization, and complement evasion. Front Immunol 7:442. https://doi.org/10.3389/fimmu.2016.00442

128. Seshu J, Esteve-Gassent MD, Labandeira-Rey M et al (2006) Inactivation of the fibronectin-binding adhesin gene bbk32 significantly attenuates the infectivity potential of Borrelia burgdorferi. Mol Microbiol 59:1591-1601. https://doi.org/10.111 1/j.1365-2958.2005.05042.x

129. Harris G, Ma W, Maurer LM et al (2014) Borrelia burgdorferi protein BBK32 binds to soluble fibronectin via the N-terminal $70-\mathrm{kDa}$ region, causing fibronectin to undergo conformational extension. J Biol Chem 289:22490-22499. https://doi. org/10.1074/jbc.M114.578419

130. Guo BP, Norris SJ, Rosenberg LC et al (1995) Adherence of Borrelia burgdorferi to the proteoglycan decorin. Infect Immun 63:3467-3472

131. Guo BP, Brown EL, Dorward DW et al (1998) Decorin-binding adhesins from Borrelia burgdorferi. Mol Microbiol 30:711-723. https://doi.org/10.1046/j.1365-2958.1998.01103.x

132. Salo J, Loimaranta V, Lahdenne $P$ et al (2011) Decorin binding by DbpA and B of Borrelia garinii, Borrelia afzelii, and Borrelia burgdorferi sensu stricto. J Infect Dis 204:65-73. https://doi. org/10.1093/infdis/jir207

133. Antonara S, Ristow L, Coburn J (2011) Adhesion mechanisms of Borrelia burgdorferi. The Prokaryotes. https://doi. org/10.1007/978-94-007-0940-9_3

134. Bryksin AV, Godfrey HP, Carbonaro CA et al (2005) Borrelia burgdorferi $\mathrm{BmpA}, \mathrm{BmpB}$, and $\mathrm{BmpD}$ proteins are expressed in human infection and contribute to P39 immunoblot reactivity in patients with Lyme disease. Clin Vaccine Immunol 12:935-940. https://doi.org/10.1128/CDLI.12.8.935-940.2005

135. Pal U, Wang P, Bao F et al (2008) Borrelia burgdorferi basic membrane proteins A and B participate in the genesis of Lyme arthritis. J Exp Med 205:133-141. https://doi.org/10.1084/ jem. 20070962

136. Monteville MR, Yoon JE, Konkel ME (2003) Maximal adherence and invasion of INT 407 cells by Campylobacter jejuni requires the $\mathrm{CadF}$ outer membrane protein and microfilament 
reorganization. Microbiology 149:153-165. https://doi. org/10.1099/mic.0.25820-0

137. Scott NE, Marzook NB, Deutscher A et al (2010) Mass spectrometric characterization of the Campylobacter jejuni adherence factor $\mathrm{CadF}$ reveals post-translational processing that removes immunogenicity while retaining fibronectin binding. Proteomics 10:277-288. https://doi.org/10.1002/pmic.200900440

138. Eucker TP, Konkel ME (2012) The cooperative action of bacterial fibronectin-binding proteins and secreted proteins promote maximal Campylobacter jejuni invasion of host cells by stimulating membrane ruffling. Cell Microbiol 14:226-238. https://doi. org/10.1111/j.1462-5822.2011.01714.x

139. Kuusela P, Moran AP, Vartio T, Kosunen TU (1989) Interaction of Campylobacter jejuni with extracellular matrix components. Biochim Biophys Acta 993:297-300

140. Moser I, Schröder W (1995) Binding of outer membrane preparations of Campylobacter jejuni to INT 457 cell membranes and extracellular matrix proteins. Med Microbiol Immunol 184:147153. https://doi.org/10.1007/BF00224352

141. Izquierdo M, Alvestegui A, Nataro JP et al (2014) Participation of integrin $\alpha 5 \beta 1$ in the fibronectin-mediated adherence of enteroaggregative Escherichia coli to intestinal cells. Biomed Res Int 2014:1-8. https://doi.org/10.1155/2014/781246

142. Torres AG, Kanack KJ, Tutt CB et al (2004) Characterization of the second long polar (LP) fimbriae of Escherichia coli O157:H7 and distribution of LP fimbriae in other pathogenic E. coli strains. FEMS Microbiol Lett 238:333-344. https://doi. org/10.1016/j.femsle.2004.07.053

143. McWilliams BD, Torres AG (2014) Enterohemorrhagic Escherichia coli adhesins. Microbiol Spectr. https://doi.org/10.1128/ microbiolspec.ehec-0003-2013

144. Jordan DM, Cornick N, Torres AG et al (2004) Long polar fimbriae contribute to colonization by Escherichia coli $\mathrm{O} 157: \mathrm{H} 7$ in vivo. Infect Immun 72:6168-6171. https://doi.org/10.1128/ IAI.72.10.6168-6171.2004

145. Gophna U, Oelschlaeger TA, Hacker J, Ron EZ (2002) Role of fibronectin in curli-mediated internalization. FEMS Microbiol Lett 212:55-58. https://doi.org/10.1111/j.1574-6968.2002.tb112 44.x

146. King P (2012) Haemophilus influenzae and the lung (Haemophilus and the lung). Clin Transl Med 1:10. https://doi. org/10.1186/2001-1326-1-10

147. Spahich NA, St Geme JW III (2011) Structure and function of the Haemophilus influenzae autotransporters. Front Cell Infect Microbiol 1:5. https://doi.org/10.3389/fcimb.2011.00005

148. Ahearn CP, Gallo MC, Murphy TF (2017) Insights on persistent airway infection by non-typeable Haemophilus influenzae in chronic obstructive pulmonary disease. Pathog Dis. https:// doi.org/10.1093/femspd/ftx042

149. Singh B, Brant M, Kilian M et al (2010) Protein E of Haemophilus influenzae is a ubiquitous highly conserved adhesin. J Infect Dis 201:414-419. https://doi.org/10.1086/649782

150. Jalalvand F, Su YC, Mörgelin M et al (2013) Haemophilus influenzae protein $\mathrm{F}$ mediates binding to laminin and human pulmonary epithelial cells. J Infect Dis 207:803-813. https://doi. org/10.1093/infdis/jis754

151. Reidl J, Mekalanos JJ (1996) Lipoprotein e(P4) is essential for hemin uptake by Haemophilus influenzae. J Exp Med 183:621629. https://doi.org/10.1084/jem.183.2.621

152. Reidl J, Schlör S, Kraiß A et al (2002) NADP and NAD utilization in Haemophilus influenzae. Mol Microbiol 35:1573-1581. https://doi.org/10.1046/j.1365-2958.2000.01829.x

153. Clark MA, Hirst BH, Jepson MA (1998) M-cell surface $\beta 1$ integrin expression and invasin-mediated targeting of Yersinia pseudotuberculosis to mouse Peyer's patch M cells. Infect Immun 66:1237-1243
154. Saltman LH, Lu Y, Zaharias EM, Isberg RR (1996) A region of the Yersinia pseudotuberculosis invasin protein that contributes to high affinity binding to integrin receptors. J Biol Chem 271:23438-23444. https://doi.org/10.1074/jbc.271.38.23438

155. Schulze-Koops H, Burkhardt H, Heesemann J et al (1992) Plasmid-encoded outer membrane protein YadA mediates specific binding of enteropathogenic yersiniae to various types of collagen. Infect Immun 60:2153-2159

156. Mikula KM, Kolodziejczyk R, Goldman A (2013) Yersinia infection tools - characterization of structure and function of adhesins. Front Cell Infect Microbiol 2:1-14. https://doi.org/10.3389/ fcimb.2012.00169

157. Han YW, Miller VL (1997) Reevaluation of the virulence phenotype of the inv yadA double mutants of Yersinia pseudotuberculosis. Infect Immun 65:327-330

158. Heise T, Dersch P (2006) Identification of a domain in Yersinia virulence factor YadA that is crucial for extracellular matrixspecific cell adhesion and uptake. Proc Natl Acad Sci 103:33753380. https://doi.org/10.1073/pnas.0507749103

159. Rosqvist R, Skurnik M, Wolf-Watz H (1988) Increased virulence of Yersinia pseudotuberculosis by two independent mutations. Nature 334:522-525. https://doi.org/10.1038/334522a0

160. Skurnik M, Wolf-Watz H (1989) Analysis of the yopA gene encoding the Yop1 virulence determinants of Yersinia spp. Mol Microbiol 3:517-529. https://doi.org/10.1111/j.1365-2958.1989. tb00198.x

161. Parkhill J, Wren BW, Thomson NR et al (2001) Genome sequence of Yersinia pestis, the causative agent of plague. Nature 413:523-527. https://doi.org/10.1038/35097083

162. Mühlenkamp MC, Hallström T, Autenrieth IB et al (2017) Vitronectin binds to a specific stretch within the head region of Yersinia adhesin A and thereby modulates Yersinia enterocolitica host interaction. J Innate Immun 9:33-51. https://doi. org/10.1159/000449200

163. Emödy L, Heesemann J, Wolf-Watz H et al (1989) Binding to collagen by Yersinia enterocolitica and Yersinia pseudotuberculosis: evidence for yopA-mediated and chromosomally encoded mechanisms. J Bacteriol 171:6674-6679. https://doi. org/10.1128/jb.171.12.6674-6679.1989

164. Kolodziejek AM, Hovde CJ, Minnich SA (2012) Yersinia pestis Ail: multiple roles of a single protein. Front Cell Infect Microbiol 2:1-10. https://doi.org/10.3389/fcimb.2012.00103

165. Miller VL, Beer KB, Heusipp G et al (2001) Identification of regions of Ail required for the invasion and serum resistance phenotypes. Mol Microbiol 41:1053-1062. https://doi.org/10.1 046/j.1365-2958.2001.02575.x

166. Tsang TM, Wiese JS, Felek S et al (2013) Ail proteins of Yersinia pestis and Y. pseudotuberculosis have different cell binding and invasion activities. PLoS One 8:e83621. https://doi.org/10.1371/ journal.pone.0083621

167. Biedzka-Sarek M, Salmenlinna S, Gruber M et al (2008) Functional mapping of YadA- and Ail-mediated binding of human factor $\mathrm{H}$ to Yersinia enterocolitica serotype O:3. Infect Immun 76:5016-5027. https://doi.org/10.1128/IAI.00314-08

168. Tükel C, Akçelik M, de Jong MF et al (2007) MarT activates expression of the MisL autotransporter protein of Salmonella enterica serotype Typhimurium. J Bacteriol 189:3922-3926. https://doi.org/10.1128/JB.01746-06

169. Raghunathan D, Wells TJ, Morris FC et al (2011) SadA, a trimeric autotransporter from Salmonella enterica serovar Typhimurium, can promote biofilm formation and provides limited protection against infection. Infect Immun 79:4342-4352. https ://doi.org/10.1128/IAI.05592-11

170. Roman J, Rivera HN, Roser-Page S et al (2006) Adenosine induces fibronectin expression in lung epithelial cells: 
implications for airway remodeling. Am J Physiol Cell Mol Physiol 290:L317-L325. https://doi.org/10.1152/ajplung.00118 .2005

171. Ringnér M, Valkonen KH, Wadström T (1994) Binding of vitronectin and plasminogen to Helicobacter pylori. FEMS Immunol Med Microbiol 9:29-34. https://doi.org/10.1111/j.1574695X.1994.tb00470.x

172. Trust TJ, Doig P, Emödy L et al (1991) High-affinity binding of the basement membrane proteins collagen type IV and laminin to the gastric pathogen Helicobacter pylori. Infect Immun 59:4398-4404

173. Heck LW, Morihara K, Abrahamson DR (1986) Degradation of soluble laminin and depletion of tissue-associated basement membrane laminin by Pseudomonas aeruginosa elastase and alkaline protease. Infect Immun 54:149-153

174. Bamford CV, Fenno JC, Jenkinson HF, Dymock D (2007) The chymotrypsin-like protease complex of Treponema denticola ATCC 35405 mediates fibrinogen adherence and degradation. Infect Immun 75:4364-4372. https://doi.org/10.1128/IAI.00258 $-07$

175. Hoy B, Löwer M, Weydig C et al (2010) Helicobacter pylori $\mathrm{HtrA}$ is a new secreted virulence factor that cleaves E-cadherin to disrupt intercellular adhesion. EMBO Rep 11:798-804. https ://doi.org/10.1038/embor.2010.114

176. Haiko J, Suomalainen M, Ojala T et al (2009) Invited review: Breaking barriers-attack on innate immune defences by omptin surface proteases of enterobacterial pathogens. Innate Immun 15:67-80. https://doi.org/10.1177/1753425909102559

177. Mühlen S, Dersch P (2015) Anti-virulence strategies to target bacterial infections. Curr Top Microbiol Immunol 398:147-183

178. Lo AWH, Van de Water K, Gane PJ et al (2014) Suppression of type 1 pilus assembly in uropathogenic Escherichia coli by chemical inhibition of subunit polymerization. J Antimicrob Chemother 69:1017-1026. https://doi.org/10.1093/jac/dkt467

179. Totsika M, Kostakioti M, Hannan TJ et al (2013) A FimH inhibitor prevents acute bladder infection and treats chronic cystitis caused by multidrug-resistant uropathogenic Escherichia coli ST131. J Infect Dis 208:921-928. https://doi.org/10.1093/infdi s/jit245

180. Han Z, Pinkner JS, Ford B et al (2010) Structure-based drug design and optimization of mannoside bacterial FimH antagonists. J Med Chem 53:4779-4792. https://doi.org/10.1021/jm100 $438 \mathrm{~s}$

181. Cusumano CK, Pinkner JS, Han $Z$ et al (2011) Treatment and prevention of urinary tract infection with orally active FimH inhibitors. Sci Transl Med 3:109ra115. https://doi.org/10.1126/ scitranslmed.3003021

182. Han Z, Pinkner JS, Ford B et al (2012) Lead optimization studies on FimH antagonists: discovery of potent and orally bioavailable ortho-substituted biphenyl mannosides. J Med Chem 55:39453959. https://doi.org/10.1021/jm300165m

183. Klein T, Abgottspon D, Wittwer M et al (2010) FimH antagonists for the oral treatment of urinary tract infections: from design and synthesis to in vitro and in vivo evaluation. J Med Chem 53:8627-8641. https://doi.org/10.1021/jm101011y

184. Jiang X, Abgottspon D, Kleeb S et al (2012) Antiadhesion therapy for urinary tract infections-A balanced PK/PD profile proved to be key for success. J Med Chem 55:4700-4713. https://doi. org/10.1021/jm300192x

185. Van Klinken BJ, Dekker J, Büller HA, Einerhand AW (1995) Mucin gene structure and expression: protection vs. adhesion. Am J Physiol 269:G613-G627. https://doi.org/10.1152/ajpgi 1995.269.5.G613

186. Parker P, Sando L, Pearson R et al (2010) Bovine Muc1 inhibits binding of enteric bacteria to Caco-2 cells. Glycoconj J 27:8997. https://doi.org/10.1007/s10719-009-9269-2
187. Krachler AM, Ham H, Orth K (2011) Outer membrane adhesion factor multivalent adhesion molecule 7 initiates host cell binding during infection by Gram-negative pathogens. Proc Natl Acad Sci USA 108:11614-11619. https://doi.org/10.1073/pnas.11023 60108

188. Krachler AM, Orth K (2011) Functional characterization of the interaction between bacterial adhesin multivalent adhesion molecule 7 (MAM7) protein and its host cell ligands. J Biol Chem 286:38939-38947. https://doi.org/10.1074/jbc.M111.291377

189. Krachler AM, Ham H, Orth K (2012) Turnabout is fair play: use of the bacterial multivalent adhesion molecule 7 as an antimicrobial agent. Virulence 3:68-71. https://doi.org/10.4161/ viru.3.1.18172

190. Krachler AM, Mende K, Murray C, Orth K (2012) In vitro characterization of multivalent adhesion molecule 7-based inhibition of multidrug-resistant bacteria isolated from wounded military personnel. Virulence 3:389-399. https://doi.org/10.4161/ viru. 20816

191. Huttunen S, Toivanen M, Liu C, Tikkanen-Kaukanen C (2016) Novel anti-infective potential of salvianolic acid B against human serious pathogen Neisseria meningitidis. BMC Res Notes 9:25. https://doi.org/10.1186/s13104-016-1838-4

192. Howell A, Souza D, Roller M, Fromentin E (2015) Comparison of the anti-adhesion activity of three different cranberry extracts on uropathogenic P-fimbriated Escherichia coli: a randomized, double-blind, placebo controlled, ex vivo, acute study. Nat Prod Commun 10:1215-1218

193. Hotchkiss AT, Nuñez A, Strahan GD et al (2015) Cranberry Xyloglucan structure and inhibition of Escherichia coli adhesion to epithelial cells. J Agric Food Chem 63:5622-5633. https ://doi.org/10.1021/acs.jafc.5b00730

194. Niehues M, Euler M, Georgi G et al (2010) Peptides from Pisum sativum L. enzymatic protein digest with anti-adhesive activity against Helicobacter pylori: structure-activity and inhibitory activity against BabA, SabA, HpaA and a fibronectinbinding adhesin. Mol Nutr Food Res 54:1851-1861. https://doi. org/10.1002/mnfr.201000021

195. Signoretto C, Canepari P, Stauder M et al (2012) Functional foods and strategies contrasting bacterial adhesion. Curr Opin Biotechnol 23:160-167. https://doi.org/10.1016/J.COPBI O.2011.08.006

196. Olsén A, Wick MJ, Morgelin M, Bjorck L (1998) Curli, fibrous surface proteins of Escherichia coli, interact with major histocompatibility complex class I molecules. MBio 66:944-949

197. Lewis SB, Prior A, Ellis SJ et al (2016) Flagellin induces $\beta$-Defensin 2 in human colonic ex vivo infection with enterohemorrhagic Escherichia coli. Front Cell Infect Microbiol 6:68. https://doi.org/10.3389/fcimb.2016.00068

198. Nakjang S, Ndeh DA, Wipat A et al (2012) A novel extracellular metallopeptidase domain shared by animal host-associated mutualistic and pathogenic microbes. PLoS One 7:e30287. https ://doi.org/10.1371/journal.pone.0030287

199. Uliczka F, Pisano F, Schaake J et al (2011) Unique cell adhesion and invasion properties of Yersinia enterocolitica $\mathrm{O}: 3$, the most frequent cause of human yersiniosis. PLoS Pathog 7:e1002117. https://doi.org/10.1371/journal.ppat.1002117

200. Kakoschke TK, Kakoschke SC, Zeuzem C et al (2016) The RNA chaperone Hfq is essential for virulence and modulates the expression of four adhesins in Yersinia enterocolitica. Sci Rep 6:29275. https://doi.org/10.1038/srep29275

201. Brzuszkiewicz E, Bruggemann H, Liesegang H et al (2006) How to become a uropathogen: comparative genomic analysis of extraintestinal pathogenic Escherichia coli strains. Proc Natl Acad Sci 103:12879-12884. https://doi.org/10.1073/pnas.06030 38103 
202. Antia M, Baneyx G, Kubow KE, Vogel V (2008) Fibronectin in aging extracellular matrix fibrils is progressively unfolded by cells and elicits an enhanced rigidity response. Faraday Discuss 139:229. https://doi.org/10.1039/b718714a
Publisher's Note Springer Nature remains neutral with regard to jurisdictional claims in published maps and institutional affiliations. 